\title{
Quantitative hermeneutics: Counting forestructures on a path from W.M. Davis to the concept of multiple-permeability karst aquifers
}

\author{
H.L. Vacher ${ }^{1}$ and Lee J. Florea ${ }^{2^{*}}$ \\ ${ }^{1}$ School of Geosciences, University of South Florida, 4202 E. Fowler Ave. NES 107, Tampa, FL 33620, USA \\ ${ }^{2}$ Department of Geological Sciences, Ball State University, 2000 W. University Ave., Muncie, IN 47306, USA
}

\begin{abstract}
Hermeneutics is the theory of interpretation. One of its major components is recognizing prejudgments, or forestructures, that we bring to our objects of study. In this paper, we construct a historical narrative of the evolution of thinking about the role of caves in relation to groundwater flow in limestone, and we tabulate forestructures as they appear in the story. This account consists of three overlapping time periods: the before and after of an incident that repelled hydrogeologists and students of karst from each other in the middle of the $20^{\text {th }}$ century; a period, up to around the turn of this century, when karst science and mainstream hydrogeology were on different tracks; and a period of convergence, now intertwining, beginning roughly in the last quarter of the $20^{\text {th }}$ century. Two influential players in our story are M.K. Hubbert, whose introduction of the Eulerian perspective of flow was a force for divergence, and R.M. Garrels, whose founding of the field of sedimentary geochemistry was a force for convergence. Other key players include F.T. Mackenzie, J.E. Mylroie, V.T. Stringfield, the U.S. Geological Survey, the Bermuda Biological Station, and the Gerace Research Center in the Bahamas, along with the historical accounts of W.B. White. Our narrative ends with the broader acceptance of the concept of multiple-permeability karst aquifers. We flag in our construction a total of 43 forestructures distributed amongst the categories of hermeneutic theory: 14 in the category of preconceptions; 9 in goals; 14 in tools such as skills; and 6 in tools such as institutions. These counts are an example of the concept of social construction of statistics, and we discuss the implications in terms of the huge number of potential combinations of forestructures that could shape alternative historical narratives of this subject over this time frame.
\end{abstract}

Keywords: $\quad$ karst hydrogeology; Floridan aquifer; eogenetic karst; equivalent porous media; sedimentary geochemistry; hermeneutics

Received 04 September 2014; Revised 29 April 2015; Accepted 3 May 2015

Citation: Vacher H.L. and Florea L.J., 2015. Quantitative hermeneutics: Counting forestructures on a path from W. M. Davis to the concept of multiple-permeability karst aquifers. International Journal of Speleology, 44 (3), 207-230. Tampa, FL (USA) ISSN 0392-6672

http://dx.doi.org/10.5038/1827-806X.44.3.1

\section{INTRODUCTION}

Philosopher of science Robert Frodeman's recent paper on geology as an interpretative, that is to say hermeneutic, enterprise contains the following passage (Frodeman, 2014, p. 74):

One consequence of the hermeneutic circle is that it puts to rest the claim that it is possible to approach an object in a neutral manner. Rather, we always come to our object of study with a set of prejudgments: an idea of what the problem is, what type of information we are looking for, and what will count as an answer. What keeps these prejudgments from slipping into dogmatism and prejudice-what makes science still possible as distinguished from ideology -is the fact that they are not blind. We remain open to correction, allowing the text or object to instruct us and suggest new meanings and approaches.

That statement effectively captures the theme of this paper, the third in a series applying Frodeman's view of geology (Frodeman, 1995, p. 962-964) as a way to organize one's thinking on the history of a geologic topic. For the first paper (Vacher \& Rowe, 1997), the topic was the Pleistocene sea-level history of Bermuda, a classic site of eogenetic karst (Vacher $\&$ Mylroie, 2002). For the second (Florea \& Vacher, 2011 ), the topic was the origin of caves in relation to 
the water table. For this paper, the topic is caves in relation to groundwater flow in carbonate aquifers. Other applications of Frodeman's hermeneutics to geologic subjects include Speidel (1996) on seismic records and Miall \& Miall (2004) on stratigraphic correlation.

\section{Principles of hermeneutic geology}

Hermeneutics is the theory of interpretation, "the art or science of interpreting texts..." which can be viewed as "a system of signs, the meaning of which is not apparent and must be deciphered" (Frodeman, 1995, p. 962). In geology, the concept of a 'text' extends to the observations in the field.

The "founding concept" (Frodeman, 1995, p. 963) is the hermeneutic circle formulated by Heidegger's Sein and Zeit (Heidegger, 1962) and referred to in the quotation in the introduction. By this concept, understanding is fundamentally circular; when we strive to comprehend something, the meaning of its parts is understood from its relationship to the whole, while our conception of the whole is constructed from an understanding its parts.... Thus, our understanding of a region is based on our interpretation of the individual outcrops in that region, and vice versa (Frodeman, 1995, p. 962).

The second principle is represented by the "prejudgments" that we bring to our object of study-as mentioned in the introductory quotation. These prejudgments are forestructures in the language of hermeneutics. There are three kinds: preconceptions, goals, and tools. The preconceptions are "the ideas and theories that we rely on when thinking about an object." The goals include "our sense of what will count as an answer." The tools are the "implements, skills, and institutions that one brings to the object of study... The nature of these tools shape the type of information collected." The tools include "the social and political structures of science... The work of science proceeds through having colleagues to bounce ideas off of, professional societies and journals to define 'hot' topics and favored lines of research, and graduate students for help with running labs and collecting samples" (all from Frodeman, 1995, p. 964).

The third principle is that human understanding has a historical component because of an inheritance effect due to the cascade of activities from our prejudgments as thought about a topic passes through what amounts to a branching decision tree. As put by Frodeman (1995, p. 964):

Hermeneutics argues (that) our original goals and assumptions result in certain facts being discovered rather than others, which in turn lead to new avenues of research and sets of facts... As these decisions get multiplied over the decades the body of scientific knowledge comes to have a strongly historical component.

In the following we give a historical account leading to the recognition of multiple permeability elements in conceptual models of karst aquifers and, in the process, identify forestructures as they occur in the story. We will label them according to the types identified above. The labels are:

FS 1. Preconceptions

FS 2. Goals

FS 3a. Tools: Skills

FS 3b. Tools: Institutions

We will also count them as we go (FS $n-m$, where $n$ and $m$ refer to the forestructure type and the specific example, respectively). At the end of the paper, we list the forestructures to begin to grasp the comment "consider the alternatives" when one contemplates a research study or the evolution of thought on a subject. We list the forestructures at the end rather than at the beginning, because they were a finding of the account rather than a guide for it.

An account such as this is obviously biased by the history and background of the storytellers. In a paper about forestructures, it would be inappropriate not to acknowledge our own. LJF, a passionate caver and life member of the National Speleological Society, was raised in Kentucky and studied caves therein. HLV was introduced to carbonates in Bermuda during 1967 for his dissertation because his advisor (Fred Mackenzie), who had funding, was interested in Pleistocene sealevel history. After that dissertation, he was hired by the Bermuda Government to advise them about their fresh groundwater and then, in that context, learned what he could about hydrogeology and freshwater lenses. We met in 2002 at a meeting of the Karst Waters Institute in Gainesville, Florida, where LJF learned of the Floridan aquifer with grainstone matrix permeability centered on $10^{-12.4} \mathrm{~m}^{2}$ (Budd \& Vacher, 2002, 2004). LJF then pursued doctoral studies at the University of South Florida, with a dissertation entitled "The Karst of West-Central Florida" (Florea, 2006).

We divide the account into three roughly chronologic sections. The first focuses on an oftencited incident that repelled hydrogeologists and students of karst from each other in the middle of the last century. The second discusses aspects of the two separate threads-karst science and mainstream hydrogeology - to around the turn of this century. The third is a personal, 50-year-long chain of observations that optimistically note that the two threads are intertwining within Atkinson's (1985) triangle of conduit, fissure, and matrix porosity. The sections overlap chronologically, rather like range zones in a biostratigraphic chart.

\section{THE BLAST FROM HUBBERT}

The magnificent account of the history of American theories of cave origin by Watson \& White (1985) in the Geological Society of America (GSA) Centennial volume on the history of American geology refers to the period 1942-1957 as "The Hiatus." Before it, there was the "classic period" in the wake of "Origin of Limestone Caverns" (Davis, 1930). After it is the "modern period." The hiatus (Watson \& White, 1985, p. 115):

came with World War II and a virtual absence of studies of cave origin from 1942 to 1957. It was not so much that no papers about caves were 
being published as it was a dearth of new ideas about cave origin.

Allyn Swinnerton, a professor at Antioch College, tried to bring the hydrogeology and karst communities together with a series of seven status reports between 1938 and 1949 with titles such as "Research on hydrology and physiography of limestone terrains" in the Transactions of the American Geophysical Union (Garrels, 1953, p. 145). This step toward a field of karst hydrology was "a promising start," but it was "squelched" (White, 2000, p. 40). It was squelched as a result of an intense criticism of Swinnerton's 1932 paper "Origin of Limestone Caves" (Swinnerton, 1932) by M. King Hubbert (1940) According to White (2000, p. 40):

Swinnerton's ideas were discredited. For the next 20 years it was held that karst aquifers were not intrinsically different from any other porous aquifer, and that caves had little if anything to do with the movement of groundwater.

Communication between the two sciences was dead, which presumably played a role in "the hiatus." This incident, the buildup to it, and its aftermath are rife with forestructures.

\section{Setting the stage: the classic period of the history of American speleogenesis.}

There is no question from the description in Watson \& White (1985) that the guiding forestructure in the classic period of American speleogenesis is "a presumption of two epochs in the history of cave development," which, in turn, was derived from the underlying forestructure of the cycle of erosion of Davis (1899) (FS 1-1). Thus (Watson \& White, 1985, p. 111):

What is striking about this hypothesis (explaining the change from earlier excavation to later deposition) is that it is presented to explain two epochs (emphasis added) of cave history which Davis merely assumes without explicit argument to have taken place. Presumably, he reasons that the cave opening must have been excavated before it can be filed with deposition. This is reasonable, but it is gratuitous to go on to assert that there is first an epoch (emphasis added) of excavation and then an epoch (emphasis added) of deposition. If one does assume that these successive epochs took place, then the problem does arise as to what caused the change from excavation to deposition. What Davis has done is taken as a given two-epoch picture of cave origin that should really be part of his hypothesis.

Why does Davis see the problem of cave origin in the two-epoch, two-cycle way? It is most probably that he is fitting a theory of cave origin to his larger theory of regional landform development according to which long epochs of stable peneplanation are interrupted by regional uplift which is followed by erosional formation of landforms in stages from youth to old age.

Davis's two-epoch forestructure (FS 1-2), and his interpretations of developing ideas in groundwater flow (e.g. King, 1913), led him to the deep-phreatic theory for the excavation epoch (FS 1-3). Swinnerton (1932) in a paper with the same title and in the same journal as Davis (1930) developed the water-table (shallow-phreatic) cave theory (Fig. 1). In an earlier paper (Swinnerton, 1929a) given at the GSA Annual Meeting, he applied it as a forestructure to interpret changes of base level (FS 1-4) in Kentucky and in Bermuda. Regarding Kentucky, he clearly was not agreeing with Davis that all the levels of in Mammoth Cave were excavated at the same time. Regarding submerged decorated caves of Bermuda, he wrote:

... various data point to a comparatively recent moderate submergence of the islands. The caves in Bermuda extend below sealevel and, in themselves, may be regarded as indicative of at least one stage of greater elevation in the history of the islands. From measurements of depth of water in the caves, allowing for fallen roof fragments, it seems evident that the islands have been submerged between 50 and 60 feet. The relation between caves and baselevel permits a quantitative approach to the problem of change of level.

In a contemporaneous paper, he was explicit and combined three forestructures (FS 1-2, FS 1-3, and FS 1-4) (Swinnerton, 1929b, p. 84).

If this correlation is correct, the evidence suggests strongly that caves were actively excavated during the first glacial advance, and that during this Nebraskan stage sea-level in Bermuda was 50 to 60 feet lower than at the present time

Two years later, Sayles (1931), his colleague in the Bermuda research, published the classic account connecting Bermudian stratigraphy with glacioeustatic sea level.

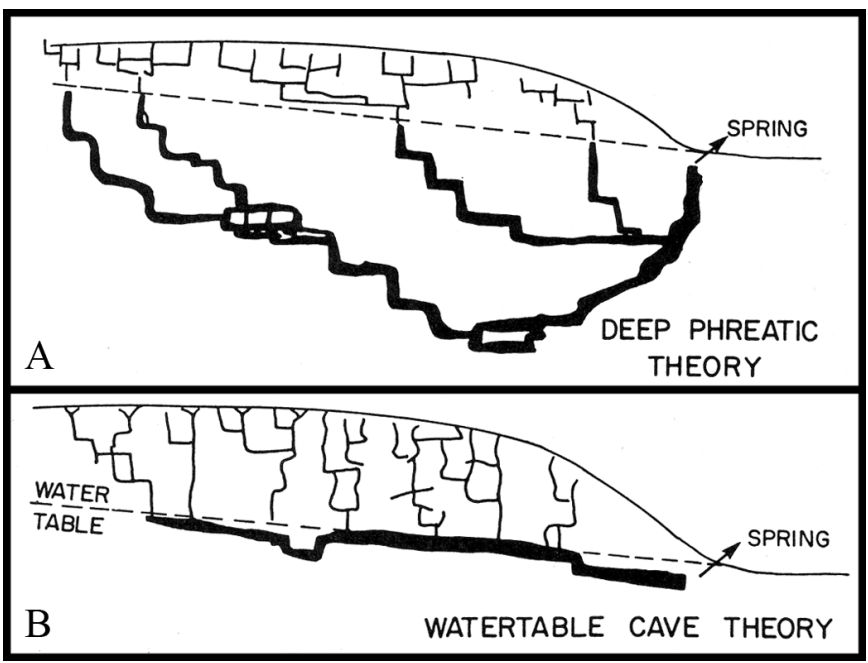

Fig. 1. Two models of cave development as recounted in this paper. A) The deep phreatic model, was that proposed by Davis (1930). B) The water-table model, that was presented by Swinnerton (1932), based upon his observations at Mammoth Cave. Figure adapted with permission from Ford and Williams (2007, Figure 3.17).

Sayles' correlation of Bermuda's stratigraphy of limestone-soil alternations with Pleistocene interglacial-glacial cycles would be revised some thirty years later by Bretz (1960). According to Watson \& White (1985, p. 114), Bretz "was a brilliant thinker who defended Davis' two-cycle theory with many 
observations in the field." They go on to note (Watson $\&$ White, 1985, p. 115) that at the end of the classic period Bretz (1942, p. 789) argued

... that many levels, e.g., in Mammoth Cave, could form at the same time in the phreatic zone, draining only as surface stream entrenchment lowers the water table.

thus preserving the deep-phreatic forestructure (FS 1-3).

As an aside it is worth noting the small-world aspects of our subject: many years earlier, Bretz, a phenomenal teacher at the University of Chicago according to Heinz Lowenstam's oral history (Lowenstam, 1991, session 6), had been Hubbert's undergraduate advisor and was fondly remembered in Hubbert's oral history (Doel, 1989, session 1).

\section{Setting the stage: Early hydrogeology}

From inception until the middle of the $20^{\text {th }}$ century, karst science and hydrogeology existed in relative isolation from each other. While karst scientists initially addressed questions of the origin of landforms and the evolution of landscapes, hydrogeologists were asking practical questions about groundwater as a resource. Deming (2001, p. 6) speaks to the guiding forestructure (FS 2-1) for hydrogeology:

Most of the advances that were made in the nineteenth century were pragmatic studies, made with the goal of obtaining a better understanding of how to use groundwater as a resource.... Most hydrogeological research during the first part of the twentieth century was devoted to groundwater utilization.

These needs led to an institution, another forestructure (FS 3b-1, the United States Geological Survey-the USGS), as described by Maxey (1979, p. 1-2):

Acceleration of agricultural, industrial and municipal development following the American Civil War resulted in unprecedented demands for knowledge in all areas of water-resources development. These demands were, in part, answered by the government in the organization and execution of the early geographical surveys sponsored by the U.S. War Department and by Congress in the late 1860's and the early 1870's. These surveys produced much substantive data but, more important, resulted in the establishment of the United States Geological Survey (USGS) in 1879, which, in turn, cleared the way for systematic studies involving sources of water supply including groundwater investigations. By 1903, the USGS had established a Division of Hydrology which by 1908 had evolved into the Division of Ground Water.

Deming (2001, p. 9) speaks to the primacy of that institution:

By 1930, there were approximately 20 professionals in the Ground Water Branch at the USGS. At the same time (1930) there were perhaps 30 to 40 individuals seriously studying groundwater in the western world.... The USGS was the center of groundwater studies in the western world. It would stay the center for groundwater studies until the 1970s.

Karst science and hydrogeology of these early years were inherently regional, and they focused on different areas. In the U.S., karst studies centered on the Mammoth Cave region of Kentucky and the Appalachian states of West Virginia and Virginia. Meanwhile, hydrogeologists, most notably of the USGS, emphasized the evaluation and analysis of groundwater in the western states. As colorfully put by Deming (2001, p. 9):

In the early part of the twentieth century the working schedule for geologists at the USGS was to go to the field in the summers and return to Washington, $D C$ in the winter.

\section{The blast}

The issue raised by Hubbert contra-Swinnerton was in a 4-page section entitled "Flow near the water table" (Hubbert, 1940, p. 166):

Apparently because of the resemblance between the topography of the water-table surface and that of the surface of the ground, it used to be commonly supposed, and the idea still prevails to some extent, that the ground-water flow is concentrated near the surface of the water table and that the flow down the slope of the water table resembles the corresponding flow down a topographic slope. The intensity of flow was supposed to diminish rapidly with depth, becoming substantially zero in a region of more or less uniform permeability at depths below the level of the lowest parts of the water table. This led to the conception of a large body of stagnant ground water beneath the superficial zone of flow.

In particular, Hubbert focused on and reproduced a diagrammatic cross-section from Swinnerton's paper that showed three possible flow paths diverging from a point in a regional flow system in rocks of uniform permeability (Hubbert, 1940, Fig. 43; Swinnerton, 1932, Fig. 1). Swinnerton had used the figure to claim that water would select the path of least resistance, the path along the water table (FS 1-3), the shortest and shallowest between the point in question and the outlet point in the valley (Fig. 2).

Hubbert's contention was that multiple paths emanating from a single arbitrary point would violate conservation of mass and, more instructively, that the shortest distance has nothing to do with the question. Rather, the question relates to the distribution of force potential within the cross-section, which he went on to deduce in terms of flow sources distributed uniformly across the water table and a flow sink at the outlet. He culminated his exposition with a cross-section showing the distribution of potential and streamlines in a uniformly recharged upland between two rivers (Hubbert, 1940, Fig. 2). This figure now is a commonplace of hydrgeology textbooks (e.g., Freeze \& Cherry, 1979, Fig. 6.1; Deming, 2002, Fig. 7.9).

The figure put to rest the notion that water passing through a homogeneous medium takes a right-angle 
A

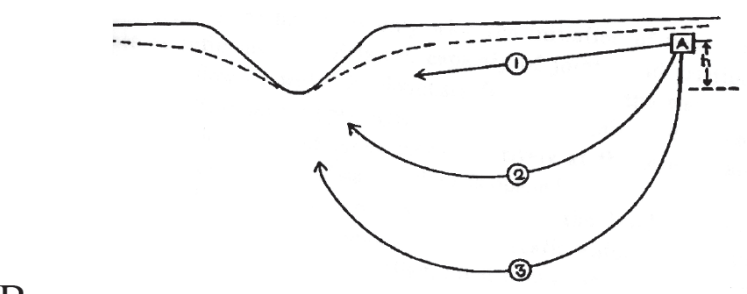

$\mathrm{B}$

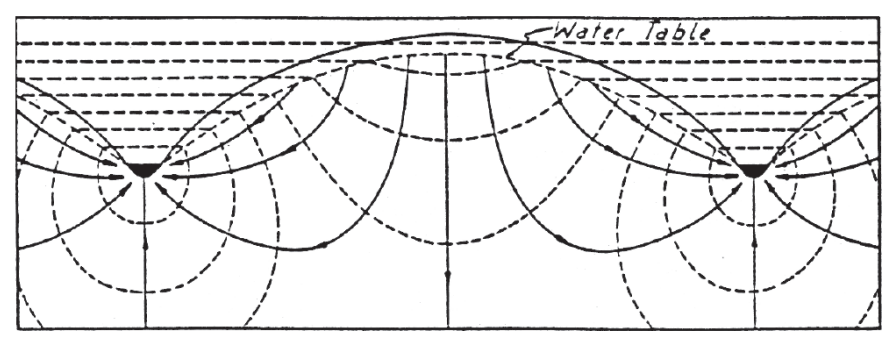

Fig. 2. A) Swinnerton's depiction of water flow in a homogeneous fractured aquifer (Fig. 1 of Swinnerton, 1932). Flowpath 1, being the shortest and along the water table, offers the least resistance to groundwater flow and, in Swinnerton's view, is the focus for the formation of caves; B) Hubbert's flow net in a homogenous, isotropic, uniformly recharged porous medium between two rivers based upon principles of field theory and Darcy's Law (Fig. 45 of Hubbert, 1940).

turn at the water table after descending vertically through the vadose zone. Thus (Hubbert, 1940, p. 170):

Hence, in Swinnerton's problem the flowlines at their points of origin, on the air-water interface always dip more steeply than the interface itself, becoming vertical at the ground-water divide..., and, across the divide, dipping in the opposite direction. Accordingly, at the divide the stream tubes descend vertically; and away from the divide, toward the valleys on either side, the angles of pitch of the flowlines gradually approach the angle of dip of the interface.... In such a region there can exist no body of stagnant water unless it be a body of water such as salt water, which is physically different from that flowing. The region of most intense flow is not a zone parallel to the air-water interface but a region where the flowlines converge toward a sink.

Hubbert's analysis was a devastating blow to Swinnerton's concept of cave development at the water table. In retrospect, it was also beside the point. Swinnerton drew his conclusion from the geological evidence of cave levels (tiers) grading to the position of rivers (FS 1-4) in strata of low structural dip and high fracture permeability - the 'ideal watertable cave' example in the Four-State Model of Ford \& Ewers (1978). The conclusion was supported by Swinnerton's (faulty) analysis of flow in a homogeneous medium, but it did not require that support. Now the argument for initial undersaturation with respect to calcite at the water table can be made on geochemical grounds (e.g., Thrailkill, 1968). Once the dissolution is initiated, the medium is no longer homogeneous. Flow is diverted into the channels of solution-enhanced permeability, and Hubbert's diagram is no longer relevant.

More to the point of the 1940 paper, Hubbert was not at all interested in the origin of caves. He had a different goal, a different forestructure. He had seized on Swinnerton's diagram to make a point about ground-water flow in general. This section, "Flow near the water table," appeared as Hubbert's first example under the general heading of "Application to Problems of Current Interest." In his introductory remarks beneath this heading, Hubbert pointed out that he was selecting examples "upon which disagreements have arisen or upon which opinions contrary to the present deductions have been held." He went on to remark that since his new theory was based on fundamental principles of physics-namely the conservation of mass and the conservation of energy-any "postulated motion of ground water" that did not conform with his theory would "be demonstrated" to be in violation of "of one or another of these principles" (all from Hubbert, 1940, p. 926). On this guiding forestructure for Hubbert (FS 2-2), Deming (2001, p. 320) says:

Hubbert was evangelical in his primary causethe application of physics and mathematics to geology. His contemporaries found this zeal irritating; but without it, the geological sciences would not have advanced. Simultaneously sensitive and abrasive, Hubbert inspired in his disciples the dual emotions of awe and sorrow. Sorrow, because Hubbert was egotistical, had a short temper, and was totally incapable of accepting criticism of any kind. Awe, because despite these personality flaws, Hubbert was a true genius who made gargantuan contributions.

\section{Aftermath: Hydrogeology}

It is impossible to overstate the importance of Hubbert's elegant, 159-page "The Theory of GroundWater Motion." By his account (Hubbert, 1969, p. 12), he wrote the paper following his analysis of the subject in preparation for his lectures on groundwater in his full-year course on geology for mining and civil engineering students at Columbia University in 1935-1937. The paper not only spells out for the first time the correct field equations of steady-state flow and the proper context of Darcy's Law. It makes the crucial distinction between pressure and potential. It defines hydraulic conductivity. It lays the foundation for quantitative hydrogeology, using concepts of mathematics within reach of confident students in first-year physics and calculus.

Although Hubbert himself considered that "the reception of this paper by ground-water hydrologists and petroleum-reservoir engineers was largely negative" (Hubbert, 1969, p. 19), that paper along with others marked a new day for hydrogeology. According to Deming (2002, p. 7):

The mathematical basis of hydrogeology was then complete. Darcy (1856) had shown that groundwater flow occurs in response to potential energy gradients. Hubbert (1940) made a complete exposition of fluid potential energy, specifying the respective roles of fluid pressure and elevation. Finally, Jacob (1940) derived an equation that made it possible to predict how potential energy gradients and thus groundwater flow would change and evolve within a porous medium. 
Domenico \& Schwartz (1990) include Theis (1935) in the transformation because he recognized the analogy between the flow of heat and the flow and groundwater and its application to well hydraulics. Why? "The significance of this finding was that heat flow was already mathematically sophisticated whereas hydrogeology was not" (Domenico \& Schwartz, 1990 , p. 4). Put another way, from that point on, mathematics became a desired forestructure for hydrogeology in terms of skills (FS 3a-1), and Darcy's Law became an implement in the toolbox (FS-3a-2).

Regarding the heat flow analogy and returning to Hubbert (1940), it is clear from his retrospective (Hubbert, 1969) that his guiding interest (FS 1-5) was the search for the scalar that would be analogous to voltage in Ohm's Law and temperature in Fourier's Law. Although one might think (Hubbert, 1969, p. 12) "as a first guess," it would be pressure, that "could not be so...by inspection." And so, it becomes clear from the retrospective that Hubbert's main target was the just-published, 700-page The Flow of Homogeneous Fluids through Porous Media (Muskat, 1937) that was the 'Bible' in the petroleum industry, for that 'Bible' was based on the (incorrect) formulation of Darcy's Law as volumetric flow being proportional to the negative gradient of pressure. The forestructure (FS 1-5) is similarly spelled out in Hubbert's oral history. Neither retrospective source mentions the origin of caves or Swinnerton. They were collateral damage.

Hubbert (1940) promoted an entire point of view that is fundamental to physics: the concept of a potential field (FS 1-6). Thus (Hubbert, 1969, p. 10):

In it (the 1940 paper) is developed in broad outline a two-field physical theory which encompasses not only the steady-state flow through porous solids of a single homogeneous fluid, but also the mutual behavior of multiple fluids in the same space. For a single fluid, the two-field theory is closely analogous to that developed a century ago for the steady-state conduction of electricity in three-dimensional space. It involves a field of force (potential) per unit of mass and a field of flow whose separate properties, together with the coupling between the two fields, determine the flow behavior.

Of these two fields, that of the force (potential) per unit mass is the most general since, for a specified fluid, it has determinate values not only in all points of space occupied by that fluid, but also at all points in exterior space capable of being occupied. This fact immediately lends itself to the treatment of the problem of multiple fluids, since there will exist a separate determinate field of force for each separate fluid throughout the same region of space.

This quotation underscores the impact of Hubbert's figure of the uniformly recharged, uniformly permeable upland between two rivers (Hubbert, 1940), for it shows both fields: the equipotentials are contours of the force potential per unit mass, and the streamlines are field lines of the velocity field (tangent to the velocity vectors) (Fig. 2). As worked out in his paper, Darcy's Law is the relationship that 'couples' the two fields.
The quotation also reveals the hugeness of Hubbert's intentions (FS-2-2). By applying the field concept to disparate fluids occupying the same mathematical space, his approach opened up to analysis the entire arena of petroleum reservoirs where gas, oil, and water reside (Hubbert, 1953, 1956), and coastal zones where fresh groundwater meets saltwater (Hubbert, 1940, p. 868-870).

Thus with Theis (1935) Hubbert (1940), and Jacob (1940), quantitative hydrogeology was, by definition, Eulerian; that is, the flow variables were described in terms of fields, e.g., without regard to what is happening to individual particles. The Eulerian description contrasts with the Lagrangian description of flow, which focuses on the individual particles. In the Lagrangian perspective, the position and velocity of individual particles are described as functions of time. The disparate points of view make a preconceptiontype forestructure (FS 1-7), which also defines goals, because it answers the question: what counts as an answer? For Eulerians, the answer is to determine the potential field (FS 2-3): a potentiometric map, or a cross-section showing equipotentials, or an analytical solution showing potential as a function of spatial variables and/or time. For Lagrangians, it may be to inject a tracer.

\section{Aftermath: Caves and karst}

Watson \& White (1985) point out that two important things happened during the hiatus of 1942-1957, during which there was, in general, disdain for caves and karst in the geological community. First was the formation of the National Speleological Society (1941) and the Cave Research Foundation (1957), which set up a mechanism of support, communication and publication. Second was a gathering of determined, communicating, young cavers (Watson \& White, 1985, p. 116):

[T]he explosion of cave studies that began in 1957 was a result of a great deal of ferment between 1942 and 1957. We are products of this era, and what we were doing-like many others-was going to school. After 1945, many of us were entitled to the G.I. Bill of Rights and universities expanded. Some of us amateur cave explorers were severely discouraged by our professors from working on karst and caves. In a cave was not where it was at. But there were a fair number of us; we knew and encouraged one another.

In other words, the young cavers mentioned in the quotation planted a forestructure (FS 3b-2), which grew into a research program that budded and bloomed the "modern period" (1957-present) of Watson \& White (1985). That community effectively founded a multidisciplinary science, speleology (e.g., Moore \& Sullivan, 1964), that was in existence in Europe since the late 1800s and is (Ford \& Cullingford, 1976, p. ix), (the) science of the cave environment (that) treats both its physical and biological aspects. It may be closely compared with oceanography, which deals with the same features of the marine environment. 


\section{SEPARATE PATHS}

\section{Speleology and karst hydrology}

Watson \& White (1985) credit geochemical work, and specifically the paper by Kaye (1957) on the process of dissolution as it occurs in flowing solvent, as initiating "the true beginning of the modern period" (Watson \& White, 1985, p. 119). One of the principal hallmarks of the modern period was a focus on process (FS 1-8). In terms of the connection between speleogenesis and groundwater, it was no longer appropriate simply to posit that dissolution happens, and it seems to happen here as opposed to there; now the question became, how does it happen (FS 2-4)? What are the chemical processes involved? How do those processes interact with the flow? Thus knowledge of dissolution geochemistry was becoming prerequisite, a forestructure (FS 3a-3), of a class of speleological studies. The other hallmarks recognized by Watson \& White $(1985$, p. 116) for the post-hiatus revival were the accumulation of data from mapping caves (FS 2-5, FS 3a-4); the incorporation of quantitative methods, particularly statistics (FS 3a-5); and arguments based on the globalized database (FS 1-9).

The dissolution geochemistry of Kaye's study was kinetics, which expanded the FS 2-4 and FS 3a-3 forestructures from that of carbonate equilibrium geochemistry alone. In particular, Kaye showed that the rate of dissolution increases with the rate of flow and thus the possibility for a positive feedback for the dissolution of a fluid pathway. Thus (Watson \& White, 1985, p. 119),

[Kaye] postulates what can be called the 'principle of self-acceleration' of cave conduits. of the various pathways through the aquifer, some will have less resistance to flow than others and thus flow velocities will be higher along these pathways. If the rate of solution increases with flow velocity, openings along these favored routes will dissolve faster. As they become larger, flow velocities will increase more, thus increasing the rate of solution still more. This is a runaway process in which the favored paths enlarge at the expense of others and ultimately become the master conduits.

Further work put the runaway process into the perspective of an evolving pore space (White, 2000, p. 41):

Cave development is effectively a runaway process, requiring that an evolving system of enlarging fractures exceed thresholds in kinetics, in the onset of turbulence, and in the onset of clastic sediment transport. Although independent, all three thresholds are reached by coincidence, when the aperture of the enlarging fractures reaches about 1 centimeter. The 1 centimeter critical aperture provides a convenient boundary between fracture aquifers and karstic aquifers (White, 1993).

By this perspective and as illustrated by the preceding quotation, karst hydrogeologists distinguished different types of karst aquifers (FS 1-10). In the most basic classification, White (1969) distinguished between

diffuse-flow aquifers, in which

solutional cavities are limited in size and number, often being mainly solutionally widened joints or bedding planes ( $p .15)$

and free-flow aquifers, in which

the ground-water flow paths have been localized by solutional modification into well integrated systems of conduits ( $p .17)$.

Atkinson (1985) used a triangular diagram (Fig. 3) to show the triple-porosity mix of granular, fissure, and conduit character within an aquifer (\% diffuse, $\%$ fissure, \% conduit, respectively; cf. Ford \&Williams, 2007, Fig. 5.29). Smart \& Hobbs (1986) cleverly divided a cube into behavioral blocks defined by three, ordinalscale Cartesian axes: (1) flow from diffuse to conduitsuccessively (a) fracture and intergranular, (b) fissure and network, and (c) conduit); (2) storage from low to high-successively (a) soil and subcutaneous, (b) seasonally saturated, and (c) perennially saturated; and (3) recharge from point to dispersed-successively (a) stream sinks, (b) subcutaneously fissures, and (c) fracture and intergranular (Ford \& Williams, 2007, Fig. 5.30).

These classification schemes, among others, emphasize that there is more to the flow of water in karst aquifers than the Darcy's Law of Hubbert (1940), no matter how fundamental that is to mainstream hydrogeology. For example, in his textbook, White (1988, p. 160) starts his discussion on the mechanics of groundwater flow, with the bold statement:

Karst hydrology is a tale of flowing water. Unlike groundwater flow in most other aquifers, water in karstic aquifers flows in pipelike conduits and open cave stream channels as well as through fractures and pores.

Then he goes on in successive subsections to discuss the equations of (1) conduit flow, (2) open channel flow, (3) porous media flow, and (4) fracture flow. For example, it is obvious that the Darcy-Weisbach equation for turbulent flow in pipes is another implement for the toolbox (FS 3a-6). The benchmark application of the Darcy-Weisbach equation was Thrailkill (1968), which discusses Mammoth Cave. Reflecting the point of view of speleology of the day, the context of the paper was process (FS 1-8), and it addressed both the hydraulics and chemistry of the flowing water.

The "flow considerations" part of Thrailkill (1968) treated a hypothetical karst flow system as an elongate network of pipes conducting turbulent water from recharge areas to a discharge site. An actual network of connected conduits worked out by Smart (1983) is shown in the textbook of Ford \& Williams (2007, Fig. 6.43). Such pipe-network conceptualizations stand in stark contrast to sandbox conceptualizations of intergranular, diffuse-flow aquifers, such as that of Hubbert (1940, Fig. 45). The two represent different ways of metaphorizing conceptual models (Vacher et al., 2006) of the permeability structure of a carbonate aquifer (FS 1-11).

Smart (1983) determined the pipe network using the premier tool of karst hydrology: dye tracing (FS 3a-7) 


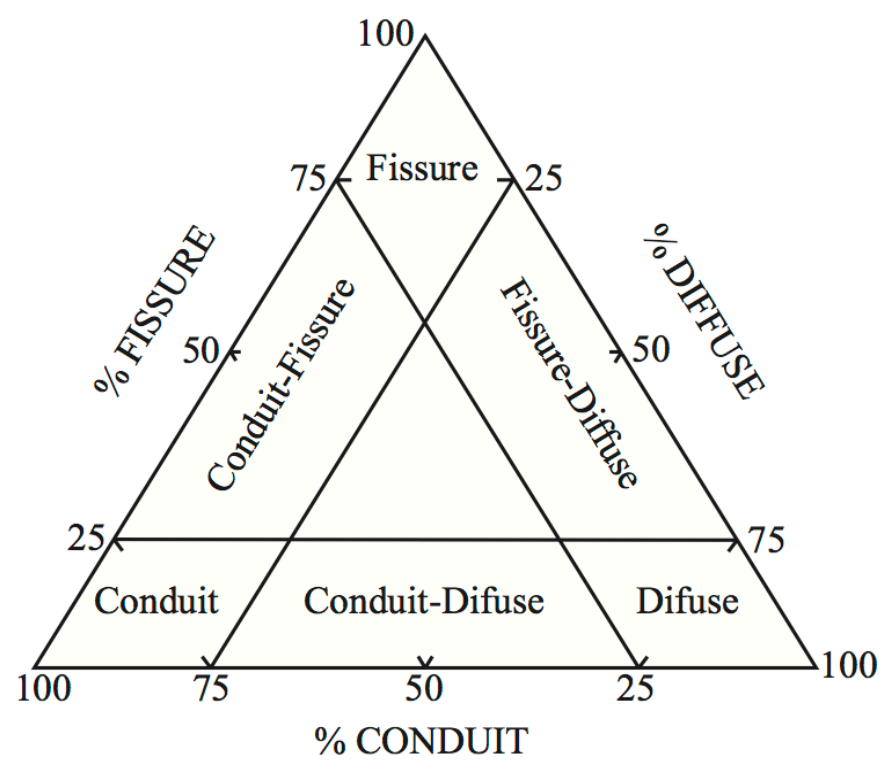

Fig. 3. Ternary diagram of types of karst permeability adapted from Atkinson (1985)

(Smart \& Laidlaw, 1977; Jones, 1984). The purpose of this technique is to determine where a tracer that is placed in a conduit emerges and how long it takes to get there (FS 2-6), thus emphasizing the Lagrangian orientation (FS 1-7). Karst hydrologists have mapped complicated multi-level and branching networks of underground rivers. They have documented how different parts of the network are activated at different stages of flows. They have shown why some springs flow only part of the year. Particularly influential in the U.S. is the work of Bill Jones in West Virginia (Jones, 1973) and Jim Quinlan at Mammoth Cave (e.g., Quinlan \& Ewers, 1989; Quinlan, 1990). Dye tracing is a skill, and maps that connect sinks to springs (e.g., Ford \& Williams, 2006, Fig. 6.39) are implements in the toolbox.

Karst hydrology gives particular attention to springs and commonly involves monitoring the spring discharge (FS 2-7, FS 3a-8). Hydrographs are the implements in the toolbox, and their utility can be enhanced by chemistry (FS 2-8); spring-flow analysis is the interpretive skill. Applications aim to quantify and understand the flood peaks (quick flow) and the sustained low flows (base flow), and in the process the relative importance of diffuse and conduit flow (White and Reich, 1970; Shuster and White, 1971; White, 1976, 1977; Atkinson, 1977)

Karst hydrology developed its own literature (FS 3b-3). Technical papers began appearing in the 1960s, many of them in the National Speleological Society Bulletin, and its successor, Journal of Cave and Karst Studies. Papers on karst invaded the mainstream geological literature (FS 3b-4) in the 1970s; for example, quoting White \& Culver (2007, p. 183),

By 1971, by and large, investigations of karst had achieved (or recovered, sic) status as respectable topics for research within the mainstream scientific community. Papers concerning karst could be submitted to the highest prestige journals with the expectation of a fair hearing and in many cases acceptance for publication. The result was a great enlargement of the literature including many contributions from scientists whose primary

interest was not caves and karst

Books on karst appeared in the 1970s (Jennings, 1971; Sweeting, 1972), and books on karst hydrology appeared in the 1980s (Bogli, 1980; Bonacci, 1987; White, 1988; Ford \& Williams, 1989; White \& White, 1989). Meanwhile, the standard textbooks of mainstream hydrogeology included little if any mention of dye tracing, underground rivers, springs or turbulence.

While dye tracing (FS 3a-7) and spring discharge monitoring (FS 3a-8) were distinctive to karst hydrology, the objective of determining the water chemistry was common to both mainstream and karst hydrology. Obviously fundamental to the question of whether or not dissolution was occurring was the saturation index of the water and what was happening with the $\mathrm{PCO}_{2}$ (Holland et al., 1968; Langmuir, 1971; Shuster \& White, 1972).

\section{Mainstream hydrogeology (Floridan aquifer perspective)}

\section{Stringfield}

The first groundwater publication of the USGS was an explanation of regional, artesian aquifers by T.C. Chamberlin (1895). This publication is said to mark the beginning of hydrogeology as an organized science (Freeze \& Back, 1983, p. 291; Meyer et al., 1988, p. 2). It was followed two years later by N. Darton's description of the Dakota aquifer, the type example of a regional artesian aquifer (Darton, 1897). The USGS was especially interested in artesian aquifers in the days of exploration for obvious reasons (FS 2-1); the natural rise of water in the well meant a ready supply of water for irrigation. About a century later, both Groundwater (Freeze \& Cherry, 1979) and Applied Hydrogeology (Fetter, 1988) were published and became leading textbooks for undergraduate courses in hydrogeology. The chapter in Fetter on regional ground water flow contained two case studies of regional artesian groundwater flow systems. One of them was Darton's Dakota aquifer. The other was the Floridan aquifer, encompassing all of Florida, together with the adjoining Coastal Plain of Alabama and Georgia.

The premier study of this great limestone aquifer was by V.T. Stringfield of the USGS (Stringfield, 1935; 1936; 1966). The work included a map of the potentiometric surface of the Floridan aquifer (Fig. 4), "a forerunner of the synoptic potentiometric maps now released annually" (Meyer et al., 1988, p. 4). The map clearly shows that just as the flow system in the Dakota aquifer is established by the water table in the outcrop area, the flow system of the Floridan aquifer in peninsular Florida is established by the water table in the outcrop area of West-Central Florida and the potentiometric surface in the Lake District of Central Florida. The outcrop area is the West-Central Florida karst, where the Floridan aquifer is overlain with little or no younger sediments (Lane, 1986; Florea, 2006). The Lake District is a buried karst terrain (Stringfield 1966; LaMoreaux, 1983), where the aquifer is confined but recharge occurs through lakes and cover-subsidence or cover-collapse sinkholes (Tihanski, 1999). 


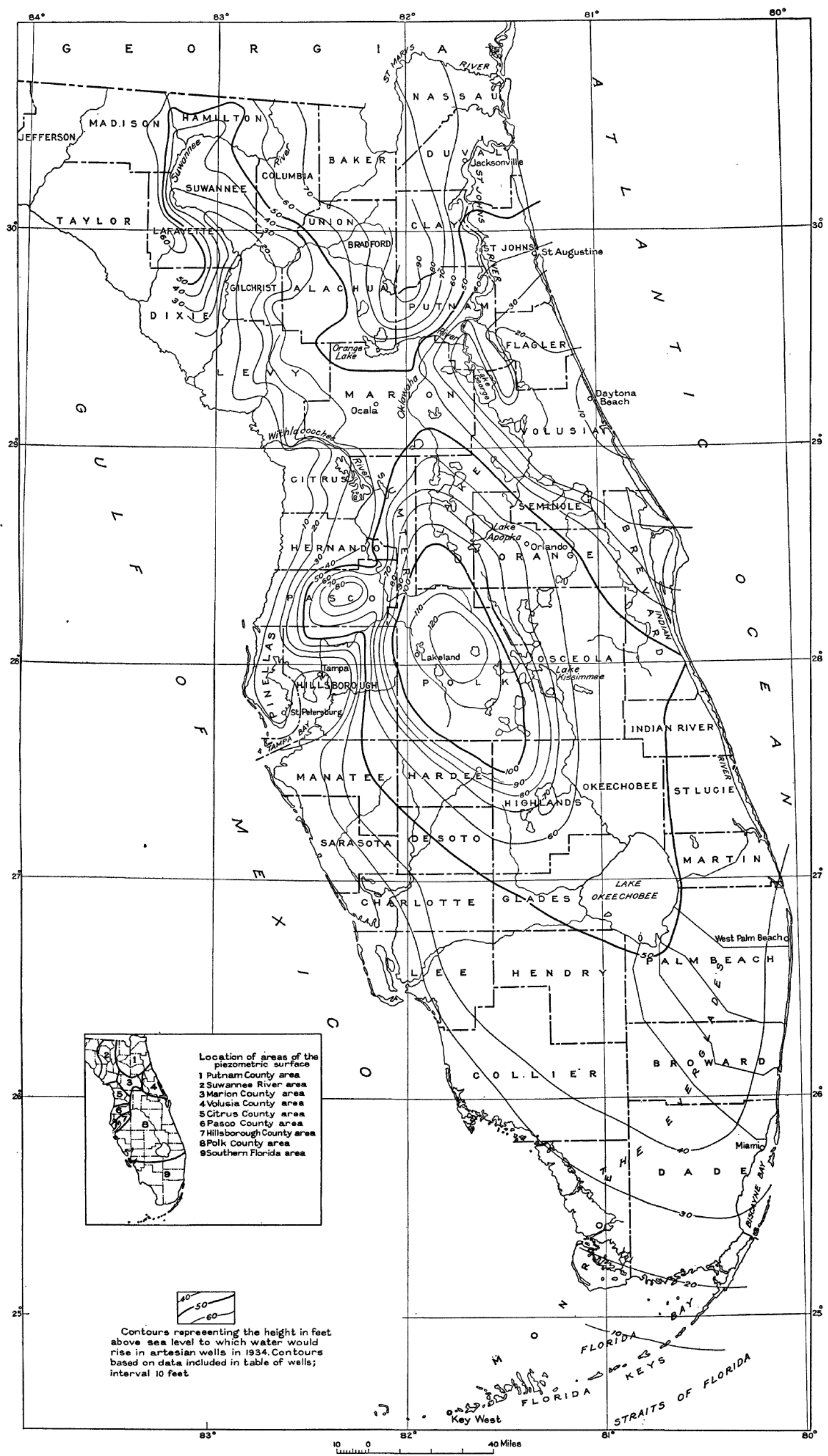

Fig. 4. Potentiometric map of the Floridan aquifer. Plate 12 of Stringfield (1936). 
The potentiometric map of the Floridan aquifer was one of the first and major products of a cooperative agreement worked out between Stringfield of the USGS and H. Gunter (Fig. 5), the second State Geologist of Florida (Meyer et al., 1988). The cooperative program that resulted from the agreement pooled the manpower, funds, and equipment of the federal and state agencies to address the major waterresources questions of the state. So successful was this cooperative program that the concept of federalstate cooperation was adopted by the USGS and the State Geologists of neighboring Georgia, Alabama, Mississippi and Louisiana. Cooperative programs spread rapidly over the U.S. (LaMoreaux, 1983).

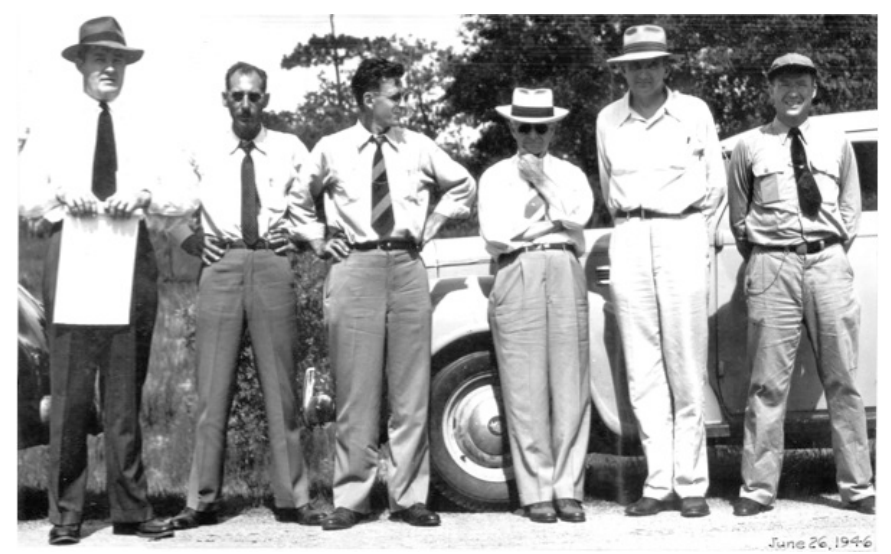

Fig. 5. Pivotal characters in Florida Hydrogeology during the mid-1940s. From left to right. Hilton Cooper (USGS), N.D. Hoy (USGS), Robert Vernon (State Geologist of Florida 1958 - 1971), Herman Gunter (State Geologist of Florida 1919 - 1958), Vic Stringfield (USGS), and Gerry Parker (USGS). Photo from the archives of the late Gerry Parker.

From 1941 to his retirement in 1972, Stringfield was Regional Division Chief of the USGS, eastern half of the U.S. Toward the end of his career and even after he retired, Stringfield produced a remarkable succession of summary publications, many with his USGS colleague Harry LeGrand. The publications were not only on the great limestone aquifer of the Southeast U.S. (Stringfield, 1966; Stringfield \& LeGrand, 1966). Of particular interest here was an outpouring of papers on what they called karst hydrology (Stringfield \& LeGrand, 1969a; LeGrand $\&$ Stringfield, 1973). These papers stressed the role of geologic factors and geologic history in the development of permeability in limestone aquifers (Stringfield \& LeGrand, 1969b; LeGrand \& Stringfield, 1971) and the hydrologic interactions of karst and coastal groundwater (Stringfield \& LeGrand, 1971).

Despite this effort, Stringfield's work was not incorporated into the mainstream publications of karst hydrology. For example, White (1988) cites only three of Stringfield's publications. Ford \& Williams (1989) cite only one, a different one than those cited by White. All references are in passing. So are references to Florida karst. Neither was Stringfield's work on karst included much in the mainstream publications in hydrogeology. For example, the eight pages on the limestone flow system of the southeastern U.S. in Fetter (1988) feature the potentiometric map of Stringfield (1966) but do not include the word 'karst' and mention caves only once (Fetter, 1988, p. 240):
In areas where the upper Floridan aquifer is unconfined, transmissivities [are extremely high] because of sinkholes and caves" (Fetter, 1988, p. 240).

Stringfield and LeGrand were not cavers, nor evidently did they interact with Florida cavers. They were unable to report about the many air-filled caves that are now known (Lane, 1986; Florea, 2006; Florea et al., 2007). Thus their papers on Florida karst lacked first-hand knowledge about caves, the premier component of karst. Although short on observations about caves, the papers were long on speculation about speleogenesis. The mainstream karst community had moved on to processes of speleogenesis, particularly geochemical processes (FS 2-4, FS 2-8). There was little of that in the papers of Stringfield and LeGrand. Moreover, the papers on the hydrology of karst were behind the times relative to Europe. Here is how White \& Culver (2007, p. 81) summarize the situation as they introduce the section on 1961-1970 in their Benchmark Papers in Karst Science:

The most important event of the period was the initiation of the International Hydrological Decade beginning in 1964.... The European members of IHD had placed karst hydrology high on their list of priorities because work in Europe was making good progress... Hydrologists in the United States found that they really didn't know much about karst hydrology. What they did know was nicely summarized in a lengthy review paper (Stringfield and LeGrand, 1969a) prepared as a baseline against which progress could be measured.

\section{Stringfield's potentiometric map as a forestructure}

What did contribute to progress was the potentiometric map (FS 2-3, FS 3a-9). In a groundbreaking hydrogeochemcial study, Back \& Hanshaw (1970) used the knowledge of the flow system provided by the potentiometric map to lay out a fence diagram of three cross-sections and 19 wells to determine the spatial variation of carbonate geochemistry in the regional aquifer (FS 2-8). The water chemistry showed systematic increases in calcium, magnesium, bicarbonate, and sulfate down gradient from the potentiometric high. To the point of mineral-rock interaction, it showed a systematic increase down gradient in calcite saturation, dolomite saturation, and $\mathrm{Mg} / \mathrm{Ca}$ ratio. It also included contours of radiocarbon age at $1,3.5,10$, and 18 thousand years.

Plummer (1977) and Plummer \& Back (1980) used four of the wells from the earlier study of Back \& Hanshaw (1970) to determine the chemical reaction that can account for the down-gradient changes in chemistry. Their method was to solve a geochemical mass-balance problem consisting of a system of simultaneous equations, one for each constituent. For example, the question of what happens to a given volume of water sampled from the potentiometric high to make it like a sample of the same volume from a downgradient site was answered by the chemical equation (Plummer \& Back, 1980, Fig. 3): 
$\mathrm{PCGW}+2.24 \mathrm{CaMg}\left(\mathrm{CO}_{3}\right)_{2}+3.56 \mathrm{CaSO}_{4} \cdot 2 \mathrm{H}_{2} \mathrm{O}+$ $+0.76 \mathrm{CO}_{2}=3.88 \mathrm{CaCO}_{3}+\mathrm{AGW}$

where PCGW is Polk City groundwater (potentiometric high) and AGW is Arcadia groundwater (down-gradient site). In a later paper, Plummer et al. (1983) extended the study to develop a reaction-path simulation model using three wells in a down-gradient series and additional data on carbon and sulfur isotopes. The net chemical reactions were "dolomite dissolution with calcite precipitation (incongruent reaction driven irreversibly by gypsum dissolution), with accompanying sulfate reduction and conservation of iron and sulfide in iron hydroxide and iron sulfide precipitation" (Morse \& Mackenzie, 1990, p. 369). The modeling produced a figure showing the reaction path in terms of water chemistry-calcium and magnesium concentrations, $\delta^{13} \mathrm{C}$, and $\mathrm{pH}-\mathrm{vs}$. a progress variable, the sulfate concentration. These geochemical reaction models were used by Plummer \& Sprinkle (2001) to improve the radiocarbon dating of the dissolved inorganic carbon in the groundwater.

Stringfield's potentiometric map was also the starting point for computer modeling of the flow system for the four-year (1978-1982) regional aquifer system analysis (RASA) study of the Floridan aquifer system. The study produced nine reports (chapters of USGS Professional Paper 1403). Two of them are of particular relevance to this paper: Bush \& Johnston (1988) for the entire aquifer system, and Ryder (1985) for West-Central Florida, where the active karst occurs. Both studies used the three-dimensional, finitedifference model of Trescott \& Larson (1976). Both studies simulated the predevelopment flow system. In the regional study (Bush \& Johnston, 1988), the grid consisted of 65 rows and 80 columns, each tile 8 miles $(12.8 \mathrm{~km})$ on a side. In the sub-regional study (Ryder, 1985), the grid consisted of 29 rows and 47 columns, each tile 4 miles $(6.4 \mathrm{~km})$ on a side.

According to an early report specifically on the predevelopment flow system (Bush, 1982), the total recharge needed to balance the total discharge occurs in the unconfined and thinly confined parts of the aquifer and amounted to about $11 \mathrm{~cm} /$ year (about $8 \%$ of the rainfall) over the recharge area. Regarding the flow system (Bush, 1982, p. 17),

The highest discharge is from the delineated areas of greatest recharge.... This implies a relatively high rate of ground-water flow in these areas where the aquifer is unconfined or partially confined, compared to that of areas where the limestone aquifer (is confined)... Another implication of high recharge and discharge in the same areas is that flow paths are relatively short.... The bulk of the recharge does not move many tens of miles from recharge areas to discharge areas. Rapid flow along short flows paths suggests a very active shallow flow system in the unconfined and partially confined parts of the limestone.

The fitted transmissivity values used in the cells are aerially distributed in a reasonable way. They are high in the unconfined and semi-confined parts of the aquifer, especially where the natural recharge and discharge are highest (e.g., springs).

Three forestructures immediately come to mind from the foregoing account of the regional hydrogeology of the Floridan aquifer. First is the significant role of the USGS in both the research and as a knowledge resource (FS 3b-1). It is also relevant that these studies, spurred by the forestructure of practical application (FS 2-1), led to new understandings of the science and new tools, both skills (modeling) and artifacts (models). In this regard it is revealing that the story involved five winners of the Meinzer award of the Hydrogeology Division of the GSA: V. Stringfield in 1970, Back and Hanshaw in 1973, Plummer in 1993, Thorstenson in 2008, and Parkhurst in 2012.

The new artifacts point to a second obvious forestructure. The USGS has long been the go-to agency for topographic maps (FS 3a-10) and geologic maps (FS 3a-11) to support geological research. Now, it is additionally the go-to agency for models. The flow model we mentioned (Trescott \& Larson, 1976) was one of several that was used in different research groups in the USGS. But (McDonald \& Harbaugh, 2003, p. 30),

As models became widely used in USGS studies, the benefit obtained from creating one program that combined the best capabilities of all the variations of model programs used in the USGS became apparent.

The result was MODFLOW (FS 3a-12). Similarly, there is a rich collection of predictive geochemical models (FS 3a-13). The USGS National Research Program and the USGS Water Resources Division provides a project to consolidate them and make them accessible (Parkhurst et al., n.d.).

The third forestructure (FS 1-12) is a necessary aspect of reconciling what Hubbert (1946, p. 275) called the "macroscopic and microscopic scales" of the porous medium. He presented the concept of the representative elemental volume (REV) as the minimum $\Delta V$ to average out the binary $1 \mathrm{~s}$ and $0 \mathrm{~s}$ inside the $\Delta V$ (1s at grains, 0 s at non-grains). Those binary elements are present at the microscopic scale like pixels in order to make a continuum like a grey scale in a photograph at the macroscopic scale. With the concept of an $\mathrm{REV}$, he could then proceed with continuum-based mathematics such as the Navier-Stokes equation. The classic figure of porosity vs. $\Delta V$ (Hubbert, 1956; Fig. 6), which is reproduced in many textbooks (e.g., Domenico \& Schwartz, 1990, Fig. 3.16), shows the porosity fluctuating widely within the microscopic domain and settling down where $\Delta V$ reaches the REV value. The idea then is that we don't care what goes on at the microscopic scale, i.e., inside the REV. With digital models (e.g., finite difference), we now have contiguous 'microscopic' tiles (pixels) kilometers on a side; two such tiles from Bush \& Johnston (1988) laid side-by-side would exceed the size of many small carbonate islands. Also, it has been found, not unreasonably, that hydraulic conductivity increases with increasing scale (Bear, 1972), i.e., the size of the averaging volume, especially in carbonate aquifers with secondary permeability (Rovey, 1994; Rovey \& Cherkauer, 1995) (Fig. 7). 


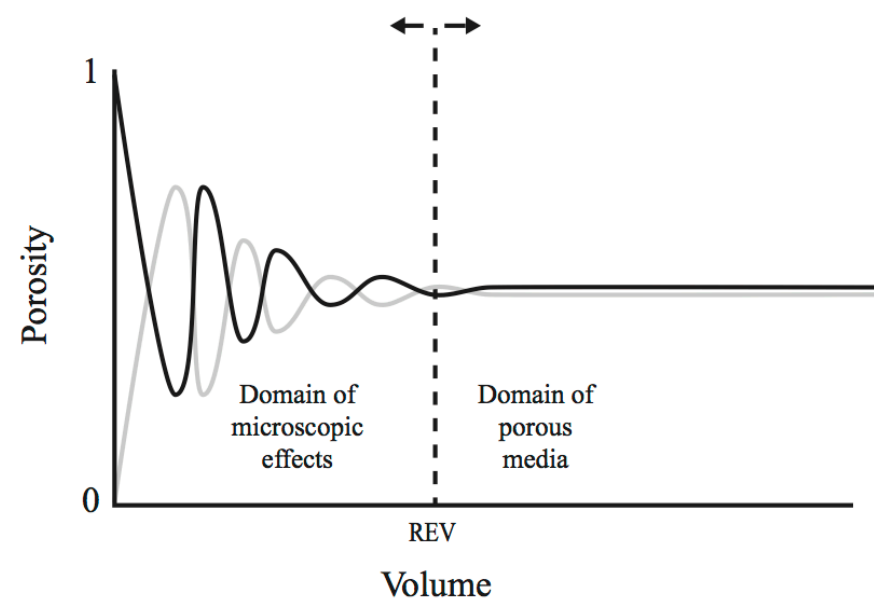

Fig. 6. The representative elementary volume concept in the 'microscopic' and 'macroscopic' regime of aquifers as adapted from Hubbert (1956).

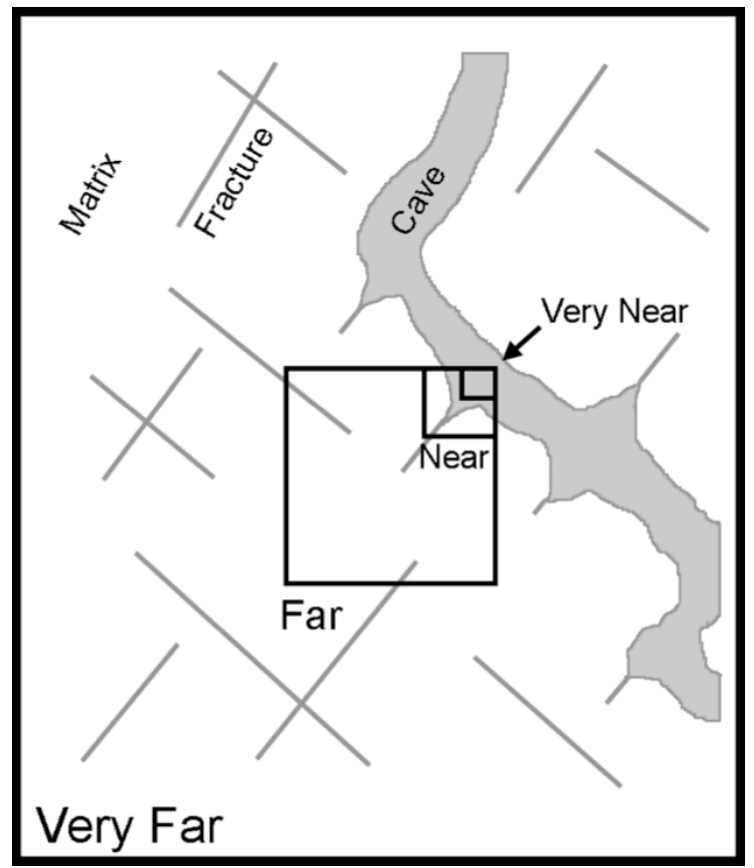

Fig. 7. Scales of permeability measurements in a karst aquifer. Terminology adapted from Bear (1972).

\section{INTERTWINING}

\section{Geochemists bring fields together}

Plummer \& Back (1980) did not limit their application of mass-balance calculations to the Floridan aquifer. One of their other examples was an evaluation of mixing of fresh groundwater with salty groundwater along the fringes of Caleta Xel Ha, a coastal lagoon along the eastern coastline of the Yucatan Peninsula, Mexico. The geomorphic significance of the geochemical work was presented by Back et al. (1979) and Back et al. (1986). Quoting the abstract of the first (p. 1521):

Where these two end-member groundwaters mix to form the brackish dispersion zone, the resulting solution is undersaturated with respect to calcite. This was confirmed by mass transfer and isotopic modeling which show that the mixing of two solutions of different ionic strength, each saturated with respect to calcite, can result in an undersaturated solution. Model calculations indicate that as much as $1.23 \mathrm{mmol}$ of $\mathrm{CaCO}_{3}$ may be dissolved per kilogram of water. We hypothesize that many of the cuspate beaches along the east coast of the Yucatan formed in this manner....

The textbook by White (1988) cites the paper by Back et al. (1979) along with another paper on the hydrochemistry of the northern Yucatan Peninsula, and five papers by Plummer and colleagues from 1976 to 1982 , mostly on the solubility of $\mathrm{CaCO}_{3}$ phases and the kinetics of calcite dissolution. The textbook by Ford \& Williams (1989) cites a different paper on Caleta Xel Ha (Back et al., 1984) and a more general paper by Back \& Zötl (1975) on applications of geochemistry to chemical principles. It also cites five papers by Plummer and colleagues, including one of the initial theoretical papers on the mixing of fresh and salty groundwater (Plummer, 1975). Obviously, the reception of these geochemical, process-oriented papers (FS 1-8) met with a different reaction than those of Stringfield and LeGrand a few years earlier. As for the argument specifically for dissolution from freshwater-seawater mixing, it certainly helped that the ground had been prepared by Mischungskorrosion, dissolution by the mixing of waters of different $\mathrm{PCO}_{2}$ (Bögli, 1964, 1980).

Geochemistry raised geologic explanation to a new level. Before geochemical models (FS 3a-13) became a part of process-oriented thinking (FS 1-8), geologic explanation of karst was simply story telling by comparison.

\section{Garrels, Mackenzie, and the Bermuda Biological Station for Research}

According to Plummer et al. (1983), the theoretical groundwork of the mass-balance geochemistry was laid by Mackenzie and Garrels (1966), Garrels \& Mackenzie (1967), Helgeson (1968), Helgeson et al. (1969), and Truesdell \& Jones (1974). White \& Culver (2007, p. 119) in their Benchmark Papers in Karst Science commented that the first version of their eighth selection, Back (1961), was written as a term paper in a course given by R.M. Garrels, who, "more than any single individual, can be considered the father of aqueous geochemistry."

As described by Berner (1989, p. 200) in connection with Garrels's Harvard years (1955-1965),

Because of Garrels, graduate students could obtain invaluable training in theoretical and experimental aspects of geochemistry, practically unobtainable elsewhere.

Berner then noted his contemporaries in the "hub of activity' that was Garrels's lab: Hanshaw, Helgeson, Truesdell, Langmuir, and Bricker, to name only those referenced in this paper. Before Harvard, Garrels headed the Solid State Group, Geochemistry and Petrology Branch, of the USGS (FS 3b-1), where he worked with Swinnerton (Garrels, 1953). After Harvard, Garrels was at Northwestern University (1965-1969), where he recruited Fred Mackenzie. Mackenzie's Northwestern students who are referenced in this paper are Plummer, Thorstenson, Lafon, Upchurch, and Vacher. All of them did dissertations or other research on Bermuda. If the forestructure, 'tools', is to include "social and political structures" that lead to 
"colleagues to bounce ideas off of" (Frodeman, 1995, p. 964), then it seems reasonable to consider networks of academic descendants as an instantiation of the idea (FS 3b-5) and identify the Garrels network as an example. Obvious examples for karst hydrology are Will White and Derek Ford (Harmon \& Wicks, 2006).

Fred Mackenzie met Bob Garrels at the Bermuda Biological Station for Research (BBSR; now, the Bermuda Institute for Ocean Sciences, BIOS) in 1962 shortly after Fred completed his PhD at Lehigh University. According to Mackenzie (1989, p. 497),

The station was an institution away from home for both us, and it became the site of many of our collaborative research efforts in the 60 s and 70 s.

In a later retrospective in Mackenzie \& Andersson (2013, p. 11), he recalled

Hal Helgeson convinced me of the importance of theoretical geochemistry in the solution of problems involving sediments and sedimentary rocks. Indeed, it was on a roll out of computer paper at BBSR that the papers to appear in Geochimica et Cosmochimica Acta (Helgeson, 1968; Helgeson et al., 1969) dealing with the evaluation of irreversible thermodynamics in geochemical processes were first worked out - Hal doing theory and Bob Garrels and I applications.

It was Keith Chave, one of his $\mathrm{PhD}$ advisors at Lehigh and a long-time friend of Garrels, who convinced Mackenzie to take a residential position at the BBSR in 1963. Chave also had two students do field work at BBSR for dissertations in Bermuda: Conrad Neumann on processes of sedimentation in one of the inland sounds, completed in 1963; and Lynton Land on meteoric diagenesis of the island's biocalcarenites, completing in 1966. One step further up the genealogical tree, Chave was a PhD student of Heinz Lowenstam at the University of Chicago (Dodd \& Stanton, 1990, p. 69), and so was Robert Ginsburg (e.g., Ginsburg \& Lowenstam, 1958). At that time, Lowenstam, who did pioneering studies of paleoecology of carbonate environments, organism-sediment relations, and biomineralization, was his Chicago colleague, Harold Urey's "Atomic Paleontologist" (Kirschvink, 2003, p. 13). Lowenstam did many disparate studies in Bermuda, including groundbreaking work in paleo-temperature determinations (e.g., Epstein \& Lowenstam, 1953) in the early days of isotope geochemistry, which is now a valued tool-type forestructure (FS 3a-14). A few years later, Lowenstam, had moved on to the California Institute of Technology, where he had a student take the first hard look at the diagenesis of Bermuda's limestone (Gross, 1961), and naturally the work included stable isotopes (Gross, 1964). About that time, Lowenstam was joined in the field (BBSR) by his former senior colleague at Chicago, Bretz, as part of a study of Bermuda's geologic history. The resulting paper (Bretz, 1960) was a milestone for its reinterpretation of Bermuda's stratigraphy, the details of which Bretz said Lowenstam would publish "before long" (p. 1732), but it didn't happen. The title of Bretz's paper, "Bermuda: A partially drowned, late mature, Pleistocene karst" lives on as a testament to the long life of the cycle of erosion (FS 1-1).

The BBSR played an important role in the developing fields of carbonate geochemistry and carbonate sedimentology with all their many interactions and individual facets. One of the individual facets was meteoric diagenesis, which is a contemporaneous phenomenon on Bermuda. The phenomenon became a theme of research for some BBSR academic descendants of Lowenstam as well as the branches from Chave, and Mackenzie (e.g., Gross, 1964; Land 1967, 1979; Land et al., 1967; Lafon \& Vacher, 1975; Plummer et al., 1976; Vacher et al., 1990; summary in Morse \& Mackenzie, 1990, p. 330-352). David Budd and Vacher, who are academic cousins (two generations down from Chave), took the theme from island-realm meteoric diagenesis (e.g., Land et al., 1967; Budd, 1984) to confined-aquifer-realm meteoric diagenesis (e.g., Niemann \& Read, 1988) by moving to the grainstone of the confined part of the Floridan aquifer and the flow paths defined by the work of Stringfield and used by Back and Plummer (Budd et al., 1993; Jones et al., 1993).

The setting and focus on meteoric diagenesis at BBSR recalled the distinction of stages of diagenesis (i.e., porosity evolution) made by Choquette \& Pray (1970). Quoting the summary in Moore (2001, p. 42),

The eogenetic stage is the time interval between initial sediment deposition and sediment burial below the influence of surficial diagenetic processes. The upper limit of the eogenetic zone is generally a depositional interface, which can be either subaerial or subaqueous....

The mesogenetic stage is the time interval during which the sediments are buried at depth below the major influence of surficial diagenetic processes.... In general, diagenesis in the mesogenetic zone ... is dominated by compaction and compaction-related processes....

The telogenetic stage is (when) carbonate sequences that have been in the mesognetic zone are exhumed in association with unconformities to once again be influenced by surficial diagenetic processes. The term telogenetic is reserved specifically for the erosion of old rocks, rather than the erosion of newly deposited sediments during minor interruptions in depositional cycles.

The distinction became a point-of-view forestructure for thinking about different types of karst (FS 1-13)

Overall, the forestructure for this meteoric diagenesis thread of the story is clearly field research stations and field schools (FS 3b-6). This forestructure is of the "social and political structures" type, under "tools." Throw groups of researchers and their graduate students together and they interact, share ideas, develop collaborations, and disperse. The BBSR example is situated in eogenetic karst. A teachingoriented example situated in telogenetic karst is the Karst Field Studies Program program of weeklong karst field studies courses at Mammoth Cave National Park, which was started by Nick Crawford of Western Kentucky University in 1979 and continues to this day. 


\section{The Gerace Research Centre, and Mylroie}

The Gerace Research Centre opened in 1971 on San Salvador Island in the Bahamas as the College Centre of the Finger Lakes (CCFL) Bahamian Field Station. It is on the site of an abandoned U.S. Naval Base that Don Gerace, the center's founder, bought for one dollar (Freid, 2011). From the beginning, Gerace's goal was to provide teaching facilities for visiting groups to conduct field courses. Now the field station (FS 3b-6) is The College of The Bahamas Gerace Research Centre. According to its website, "Each year, more than 1200 students from over 80 colleges, universities, and educational organizations participate in archeology, biology, geology, and marine science field courses." In addition, there is a regular Symposium on the Geology of the Bahamas that started in 1982. The proceedings volumes are available on the Center's website. The geology proceedings volumes contain a considerable island karst literature (FS 3b-3).

In 1977, John Mylroie and James Carew began a collaboration to establish a geologic framework for San Salvador Island (Carew \& Mylroie, 1985). Carew's role was to develop the stratigraphy (FS 2-9). Mylroie's role was to develop a dataset of the caves (FS 2-5) (Mylroie, 1983; 1984). As was the case in Bermuda (Bretz 1960), the cyclic alternation of limestone (largely eolianite) and red soils was seen to reflect Pleistocene sea-level cycles (interglacial and glacial periods, respectively). Carew and Mylroie found that nearly all of the exposed eolianites and associated coastal deposits were from the last interglacial (MIS 5e), with the coastal deposits extending up to $6 \mathrm{~m}$ elevation. Mylroie and Carew found that many caves on San Salvador, and on other islands in the Bahamas, occur within these young rocks and cluster at elevations consistent with the MIS-5e highstand. Mylroie and Carew concluded that these caves are markers of former sea levels, and they must have been produced rapidly (< $10 \mathrm{ky})$, within recently deposited sediments. These caves, which formed contemporaneously with the early diagenesis of the rocks enclosing them, are flank margin caves, so named because they are along the flanks of eolian ridges at positions occupied by the margin of the former freshwater lenses (Mylroie \& Carew, 1990; Mylroie \& Carew, 1995; Palmer, 2007, p. 211).

Early interpretations of cave origin for these islands were challenging. In the first two Geology of The Bahamas Symposia, Mylroie (1982, 1984) referred to the caves he was mapping as conduits, a loaded word. Ten years later, he had this to say about the distinctive morphology (Mylroie \& Carew, 1995, p. 63):

That morphology includes large, globular chambers, bedrock spans, thin bedrock partitions between chambers, tubular passages that end abruptly, and curvilinear phreatic dissolutional surfaces. These caves lack ablation scallops, stream channels, and other indications of turbulent conduit flow. Flank margin caves are not conduits, but rather mixing chambers. They receive water from the lens in the island interior as diffuse flow, and discharge that water, after mixing, as diffuse flow to the sea.
Now the morphology of globular chambers and terminating passages is summed up with the word, spongework (e.g., Palmer, 1991). The glossary in Palmer (2007, p. 413) defines spongework as

Interconnecting voids like those in a sponge, usually formed by the solutional enlargement of intergranular pores. A spongework maze contains openings large enough to explore.

The idea that the flank margin caves are mixing chambers rather than conduits led Mylroie \& Carew (1995, p. 63) to add these two key sentences to the paragraph quoted above:

The caves develop without an external opening to the sea or the land. Entry today is gained as a result of surface erosion breaching the cave.

In other words, by their view, flank margin caves are hypogenic (Klimchouk, 2007), meaning "they owe their origin to processes beneath the surface" as opposed to epigenic, meaning "their origin depends on acids derived from surface or near-surface processes, such as $\mathrm{CO}_{2}$ production in the soil" (both from Palmer, 2007, p. 209). Indeed, Palmer (2007) includes caves formed in seacoast mixing zones as the first example in his section on hypogenic caves. The other types are hydrothermal caves and sulfuric acid caves such as Carlsbad Caverns.

The contrast in terminology between Mylroie (1982, 1984) and the quotation from Mylroie \& Carew (1995) suggests a shift in a preconception-type forestructure when looking at Bahamian caves (FS 1-14). It is normal when thinking of caves to think of epigenic origins. After all (White, 1988, p. 284):

seen in true context, the theory of cave origins is nothing more than the theory for the development of the conduit permeability of a carbonate aquifer.

But then, 12 years later (White, 2000, p. 42), Throughout the classic period, and well into the modern period, the one paradigm that was agreed upon was that solution caves formed by the dissolution of carbonate rocks by shallow circulating groundwater carrying dissolved carbon dioxide. One of the most significant discoveries of the latter part of the modern period is that at least three alternative mechanisms (mixing zone, hydrothermal, sulfuric acid) lead to the formation of caves, and the caves formed by these processes are by no means rare.

The emergence of these new cave types happened about the same time. In particular, the new interpretation of Carlsbad Caverns (Hill, 1987, 1990) especially excited the karst community and likely was a forestructure (FS 1-9) for Mylroie. It can be noted too that the hypogenic, sulfuric-acid interpretation of Carlsbad replaced the earlier epigenic interpretation by Bretz (1949).

The hypogenic speleogenesis of flank margin caves (Palmer, 2007, Figs. 8.38, 8.44) focuses on mixing and the margin of freshwater lenses, though recent geochemical data draw attention to increased $\mathrm{PCO}_{2}$ in the vadose zone (Gulley et al., 2014a). At the water table, there can be Mischungskorrossion of Bögli (1964), and, at the base of the lens, there is freshwater- 
seawater mixing (Plummer, 1975; Back et al., 1979). The two dissolution zones merge at the shoreline edge of the lens (Mylroie \& Carew, 1995; Mylroie et al., 1995), where both the tidal motion and the net shoreward drift of water are greatest. The enlarging voids, and the focused recharge into them, would result in landward progression of the reaction front as theorized in a different environment and context by Rhoades \& Sinacori (1941). The mixing chambers can become the site of brackish sea-level pools, and vadose freshwater drips into them can continue to produce undersaturated water (Palmer et al., 1977; Palmer, 2007). The flank margin caves develop as "beads on a string" (Mylroie \& Carew, 1995), and the strings successively parallel the shoreline with fingering extensions inland. The process continues until the favorable geochemical conditions change, for example, as a result of sea-level change.

\section{The Karst Waters Institute}

Mylroie was deeply entrenched in the speleological community. A member of the NSS since 1970, his first publication cited in Palmer (2007) is from epigenic karst of the Helderberg Plateau, New York (Mylroie, 1977), and he served in various organizational and editorial positions for the society in the 1970s and 1980s. He was an instructor (advanced cave exploration; karst geology; cave survey and cartography) at the Summer University in the Park Series, Mammoth Cave National Park for eleven years beginning in 1985. Then, in 1988-1991, he worked with cave biologist Dave Culver (American University) and karst hydrologist Bill Jones (West Virginia) on the notion of a U.S. karst research institute. That effort led to the formation and, in November 1991, incorporation of the Karst Waters Institute (KWI). The mission of the 501 (c)(3) non-profit institution is "to improve the fundamental understanding of karst water systems through sound scientific research and the education of professionals and the public." Mylorie was its first president (1991-1995) and remained on the board for several more years.

The KWI (FS 3b-2) is known for its history of multidisciplinary conferences and symposia beginning in 1994. Several of them have resulted in proceedings volumes (FS 3b-3). Particularly relevant to this paper is the volume from the conference on karst modeling in 1999. The editor focused the introduction on the multiple-porosity nature of karst aquifers (Palmer, 1999, p. 2)

...Most karst specialists center their attention on solution conduits (especially caves, which are voids large enough to enter). Karst hydrology also involves the hydraulics of pipes and open channels. In contrast, traditional hydrologists view karst mainly from well data, and petroleum geologists rely mainly on borehole data and geophysics. These latter methods provide useful information about porosity and geology structure but tend to overlook the influence of solution conduits.

...Most water wells in karst draw their supply from narrow fissures and intergranular pores that support laminar flow.... The majority of the storage volume is normally in the laminar-flow openings....

Karst specialists are usually alone in emphasizing the turbulent-flow portions of the aquifers. Although conduits represent only a small percentage of the porosity, they carry most of the discharge, and at velocities that are extraordinarily high by groundwater standards. They behave in the same manner as surface rivers - serving as outlets for the surrounding laminar flow during low flow, leaking water to the surrounding parts of the aquifer when perched, supplying "bank storage" during floods, and influencing local heads within the aquifer. Any karst study involving contaminant studies or well-head protection zones that does not consider conduit flow is seriously flawed.

Within the volume, White (1999) called attention to the 'triple permeability' conceptual model consisting of the matrix (or granular) permeability of the bedrock itself, fracture permeability, and conduit permeability (Fig. 3). Following Teutsch \& Sauter (1991), he reviewed how the three types operate at different scales (FS 1-12): the rock matrix measurable at the laboratory scale; the fracture permeability needing to be averaged over a large volume of rock; and the conduit scale operating on a scale of kilometers to tens of kilometers (Fig. 7). Worthington (1999) attached numbers for porosity, permeability, proportions of storage, and proportions of flow for the three types of porosity from review of a Silurian dolostone aquifer in Ontario, the Mississippian aquifer at Mammoth Cave, the Cretaceous Chalk in Britain, and the limestone aquifer in the Yucatan Peninsula. According to Worthington (1999, p. 35)

In all four cases, more than 90\% of the aquifer storage is in the matrix and more than 90\% of the flow is in channels (conduits), with fractures playing an intermediate role

Also in that volume, Halihan et al. (1999) focused on the Edwards Aquifer in Texas, compiling permeability data from 493 core samples ("small scale"), 1072 drawdown and specific capacity tests ("well-scale"), and 3 regional modeling and hydrographic analysis studies ("regional scale"). Plotting cumulative frequency distributions for log permeability, they showed that the three sets of data were roughly log normal, with the permeability types differing by $2-4$ orders of magnitude (median $k$ at $10^{-15}, 10^{-11}$, and $10^{-9} \mathrm{~m}^{2}$, for small-scale, well-scale and regional-scale populations, respectively).

Three years later a symposium was held in Gainesville, Florida, in the heart of the karst area of the Floridan aquifer. In the introduction to the special volume, Martin et al. (2002, p. 1) explain the theme of the symposium,

Relatively little work has focused on porous unaltered carbonate settings compared with earlier work on recrystallized rocks. For example, major textbooks ... all mention Florida as an important karst area, but spend relatively little time describing and explaining the karst found there. This hole in the knowledge of hydrologic 
behavior of porous karst was the primary impetus for holding the symposium, "Karst Frontiers: Florida and Related Environments"....

For many, the highlight of the meeting was the keynote talk given in the opening evening session by Bill Wilson. He pointed out (Wilson, 2002, p. 5),

In the absence of useful results from karst hydrogeologsts, hydrologic modelers (have) resorted to applying diffuse flow equations to cavernous aquifers saying, '... at the scale of a coarse mesh digital model (with grid-block spacing of $5-10 \mathrm{~km}$ or more), flow in the karst springs area realistically can be treated as porous-media flow.' This nonsensical statement claims that first-magnitude karst springs basins can be 'realistically' modeled with fewer than four points. Even more disturbing is the fact that transmissivity values used to balance the water input and output are so high that they cannot exist in granular media, even if the Floridan Aquifer was made of bowling balls! Such models should be immediately recognized as intellectually dishonest. They predict contaminant transport velocities that are too fast for the matrix and too slow for the conduit networks. Both permeability components are poorly modeled and accurate contaminant migration predication are impossible.

Wilson (2002), a cave diver, environmental consultant, and avid collector of data on underwater caves, went on to summarize what he knew of the conduits from underwater cave maps and heights of caves intersected by wells (FS 2-5). He reported (Wilson, 2002, p. 6), among other things,

The probability of intercepting a cave is commonly about 25\% per $30 \mathrm{~m}$ of drilling and rises to about $50 \%$ in some zones.

The median height of 128 cavities, intercepted by 400 wells in Polk County was $1.28 \mathrm{~m}$ and the geometric mean was $0.76 \mathrm{~m}$.

From the cave diving data, he approximated that the conduits are elliptical with a geometric-mean heightweight ratio of 0.32 . Using the aspect ratio and the relation between average and maximum intercepts for an ellipse, the adjusted values for the geometric means for the minor and major axes were $0.98 \mathrm{~m}$ (height) and $2.9 \mathrm{~m}$ (width) giving an area of $2.2 \mathrm{~m}^{2}$ from the bit drop data, assuming similar ellipticalsection conduits. Cave density he estimated to be at least $1600 \mathrm{~km} / \mathrm{km}^{3}$ ! Continuing (Wilson, 2002, p. 7),

If distributed uniformly, then the average distance between cave passages would be about $100 \mathrm{~m}$ both horizontally and vertically... Analysis of cave lengths for 223 surveyed caves...shows that the median cave length is $38 \mathrm{~m}$. This is probably a reasonable measure of typical abandoned cave segment length.

There were 47 other papers at the symposium. Four of them of them dealt specifically with hydrogeologic properties or behavior of one or a combination of the porosity elements of the Floridan aquifer (White, 2002; Budd \& Vacher, 2002; Smith et al., 2002; Palmer, 2002). There were also groups of papers about young carbonate islands, the Yucatan, and the Edwards aquifer. The field trip (Martin \& Portell, 2002) was the vicinity of Ichetucknee springs, in the boundary zone of the confined and unconfined portions of the Floridan aquifer, the general hydrogeochemical setting of which Upchurch (2002) summarized the preceding day. The main attraction was the Santa Fe Sink/Rise system where Martin \& Dean (2001) had evidence that water flows from the conduits into the matrix during floods and from the matrix into the conduits during low-flow conditions. Tragically, Bill Wilson suffered a fatal heart attack on the bus during the field trip. KWI awards an annual memorial fellowship in his honor.

In the following few years, there was an outpouring of new papers on the exchange of water between conduits and matrix, the resultant enlargement of the conduits, the role of diffuse recharge in supplying the springs, the role of the high matrix permeability in shaping the spring hydrographs, the morphology of the caves that do not appear to be conduits, the occurrence of caves in levels, and the origin of the conduits in a time frame of Pleistocene eustasy (Screaton et al., 2004; Martin et al., 2006; Florea, 2006; Florea \& Vacher, 2006, 2007; Ritorto et al., 2009; Moore et al., 2009, 2010; Gulley et al., 2011, 2013, 2014a and b). In all these papers, the guiding thought was that the Floridan aquifer represents a karst with high matrix permeability due to its intergranular porosity as opposed to closely spaced fissures (FS-11). This mirrors an overall rise in published literature about karst at the same time, captured in Fig. 8 as the increase in abstracts on karst presented at GSA meetings. In fact, karst as a discipline was incorporated as an official GSA Division in October of 2014.

In the midst of that outpouring of new data, acceptance of karst research, and new thoughts about the Floridan aquifer, the KWI held a Frontiers of Karst Research workshop in San Antonio in 2007. One of the focus groups was on conceptual models, aquifer characterization, and numerical modeling of karst aquifers. Here are two short excerpts from their report the section on conceptual models (Sauter et al., 2008, p. 77 and 78):

In recent decades, it has been realized that karst processes must be considered in a broader context than the traditional dissolution in circulating meteoric water.... Models for karst aquifers developed in diagenetically mature, wellcompacted carbonate rocks usually need to take account only of the conduit permeability and the fracture permeability. Matrix permeability is often very low although it is sometimes substantial.... Other aquifers develop in young carbonates where diagenetic processes may be incomplete. In (these) karst aquifers, matrix permeability is usually a dominant part of the flow system. Fractures may be a relatively minor feature.

The high matrix permaeability creates a large accessible storage that is a significant contribution to the flow system. Flow in the matrix can be modelled as classical Darcian flow. However, it is difficult to account for extensive 


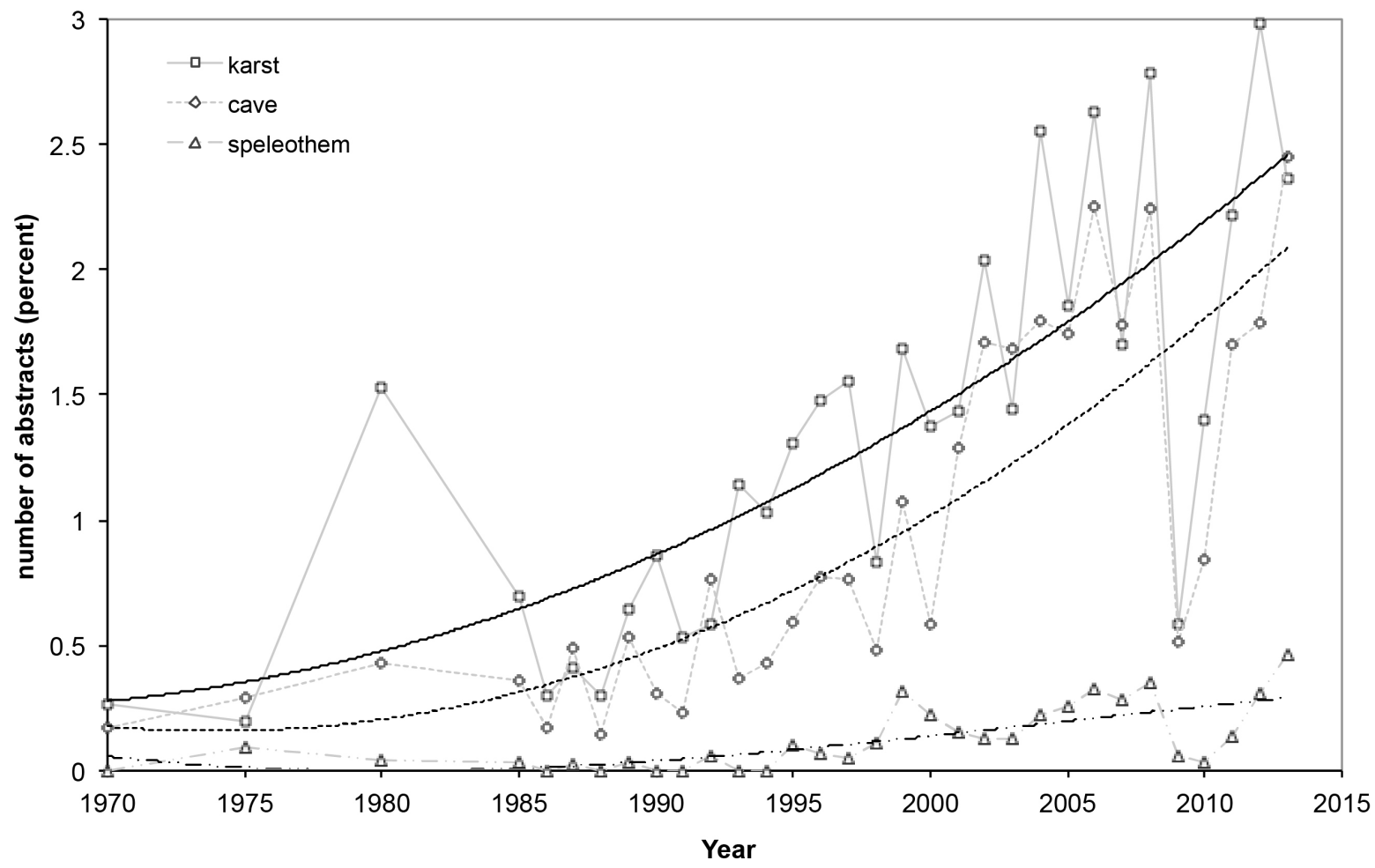

Fig. 8. Percent of abstracts at Geological Society of America meetings with best-fit polynomial regressions that include the word 'karst' (open squares - solid line), 'cave' (open diamonds - short dash line), and 'speleothem' (open triangles - dash and dot line). Data from the Geological Society of America.

conduit development in such aquifers, but the conduits are definitely present. Quantitative models must then address the interchange of conduit flow and matrix flow.

\section{A NOTE AT THE END OF OUR PATHWAY}

As expected, the account ends with triple permeability in karst aquifers-conduits, fissures, and matrix. Combinatorially, that means $2^{3}-1$, or 7 , possible combinations of one or more of the permeability elements: (1) conduits, (2) fissures, (3) matrix, (4) conduits and fissures, (5) conduits and matrix, (6) fissures and matrix, and (7) conduits, fissures and matrix. These are the three vertices, three sides, and interior region of the triangle proposed by Atkinson (1985) (Fig. 3).

Interestingly, as our conception of karst moves forward, so do our forestructures and therefore the system of signs that comprise the language. The revised language may open the door for renewed discussion and new interpretations. For example, long-term investigations from the Madison Group of the Black Hills, summarized in Palmer \& Palmer (2008), demonstrate that paleokarst can be polygenetic and multi-generational, including eogenetic through telogenetic phases of dissolution, brecciation, void filling spar, and overprinting of earlier voids. Another example, from north-central Ohio, by Torres (2012), also suggests a polygenetic origin for paleokarst in Silurian-Devonian limestone comprising an upper permeable zone associated with a telogenetic phase of conduits linked with the Pliocene pre-glacial surface and the deeper Newburg Zone with characteristics reflective of eogenetic karst developed during shifts of eustatic sea level along the flank of the Findlay Arch.
The above examples suggest directionality to the evolution of carbonate aquifers that includes karst processes at all stages. Is there, perhaps, a fourth permeability element brought about by the recognition of early eogenetic, or more generally, hypogenic karst? For example, picture, as in the Black Hills, a permeability assemblage for an aquifer reflecting a multi-generational, or polygenetic situation: an early stage with isolated cave blobs (spongework porosity, Palmer, 2007, Fig. 9.72) scattered through a fissured rock with high intergranular porosity, overprinted by a modern epigenic stage with circulating meteoric water. With such thinking involving a spongework element in addition to conduit, facture, and matrix elements, we would have more than twice as many combinations: $2^{4}-1$ or 15 .

\section{A MULTITUDE OF PATHWAYS}

The three principles of hermeneutics outlined by Frodeman (1995) are the hermeneutic circle, the relevance of forestructures, and "the decisive role of narrative logic in (the) explanations" of historical sciences (Frodeman, 1995, p. 966). He cites the claim of Ricoeuer (1985) that "narrative is our most basic way of making sense of experience" (p. 966), and we have constructed one such narrative concerning the lead up to a karst topic of particular interest to us. The overall approach prompted this welcome response from one of our reviewers:

(The) human element - how the ideas of each person writing the research papers were influenced by their personal experiences, collaborations, and education - is just as important (in some cases, perhaps more important) in understanding the evolution of 
research ideas as the data presented in the papers that present those ideas.

We obviously agree, and we wish to add the notion that the inherent subjectivity of the "human element" means that any one narrative is necessarily limited. How limited? Perhaps we can get a feel for the immensity of the universe of possible constructions from the count of forestructures flagged in our narrative.

The forestructures flagged in our constructed story are collected in Table 1 . The count is 43 in the four categories: 14 in preconceptions, guiding concepts, and points of view; 9 in goals; 14 for tools, skills, and implements; and 6 for institutions. But "people count" (Best, 2002), and so statistics (i.e., counts) are themselves socially constructed (Best, 2001, 2008). Without question, other narrative accounts starting with W.M. Davis and ending with the concept of multiple-permeability karst aquifers would take different routes and produce different collections and counts of forestructures. Our construction is heavily influenced by the historical writings of Will White (Watson \& White, 1985; White, 2000; White \& Culver, 2007), the history of one of us in Bermuda, the history of the other of us in Kentucky, and the history of both of us in Florida and the Bahamas. How many other possible lists of forestructures could there be for narratives bridging between those two points in the evolution of thinking about groundwater flow in karst aquifers?

Any answer would require arbitrary assumptions, but the message from Table 1 is that combinatorial consideration of forestructure counts will produce huge numbers of possibilities for alternative lists and alternative narratives. For example, focusing solely on the 14 preconception-type forestructures of Table 1, and considering alternative narratives involving combinations of five to nine of those 14 forestructures, there could be some 13 thousand pathways (stories, constructions) from Davis to multi-permeability karst aquifers (where two stories are 'different' if they involve a different set of preconception-type forestructures). Moreover, we certainly do not make any claim that our list is exhaustive. Suppose, for example, that our list of FS-1 forestructures is only 2/3 complete, i.e., suppose the list was increased from 14 to 21 preconceptions. That would increase the 13 thousand combinations of five to nine of the 14 FS-1 forestructures to about 688 thousand combinations of five to nine of 21 FS-1 forestructures.

Then how would the stories told from the different viewpoints, meaning different and likely larger lists of forestructures, differ from our construction? For example, we would be interested to see our subject through the lens of Peter Smart and his career pathway including examples from dye tracing (Smart \& Laidlaw, 1977), telogenetic karst (Smart \& Christopher, 1989), and eogenetic karst (Smart et al., 2006)? Additionally, we wonder how Ronald Green would write this story, incorporating his perspective from numerical modeling of karst aquifers and conceptualizing their multiple permeability (Green et al., 2006; Sun et al., 2012)? Such, it seems, is the
Table 1. Forestructures identified in the narrative.

\begin{tabular}{|c|c|}
\hline \multicolumn{2}{|c|}{ Preconceptions, guiding concepts, points of view } \\
\hline FS $1-1$ & Cycle of erosion \\
\hline FS $1-2$ & Two-epoch cave development \\
\hline FS $1-3$ & $\begin{array}{l}\text { Vadose, deep-phreatic, or shallow-phreatic (water-table) } \\
\text { speleogenesis }\end{array}$ \\
\hline FS $1-4$ & Base levels and base-level cycles \\
\hline FS $1-5$ & Concept of potential \\
\hline FS $1-6$ & Concept of field \\
\hline FS $1-7$ & Eulerian vs. Lagrangian description of flow \\
\hline FS $1-8$ & Process-oriented thinking \\
\hline FS 1-9 & Awareness of other examples and settings \\
\hline FS $1-10$ & Classification of karst aquifers \\
\hline FS $1-11$ & Metaphors such as pipe netoworks and sandboxes \\
\hline FS $1-12$ & Scale of averaging volumes \\
\hline FS $1-13$ & Eogenetic vs. telogenetic karst \\
\hline FS $1-14$ & Epigenic vs. hypogenic karst \\
\hline \multicolumn{2}{|r|}{ Goals } \\
\hline FS 2-1 & Practical application \\
\hline FS 2-2 & Apply fundamental principles of physics \\
\hline FS 2-3 & Map the potential field \\
\hline FS 2-4 & Understand dissolution processes \\
\hline FS 2-5 & Locate and map the caves \\
\hline FS 2-6 & Join sinks to resurgences \\
\hline FS $2-7$ & Monitor and interpret spring discharge \\
\hline FS 2-8 & Determine the water chemistry \\
\hline FS 2-9 & Establish the stratigraphic framework \\
\hline \multicolumn{2}{|r|}{ Tools, skills and implements } \\
\hline FS 3a-1 & Mathematics \\
\hline FS 3a-2 & Darcy's Law \\
\hline FS $3 a-3$ & Aqueous geochemistry \\
\hline FS $3 a-4$ & Cave mapping and cave maps \\
\hline FS $3 a-5$ & Descriptive statistics \\
\hline FS 3a-6 & Darcy-Weisbach equation \\
\hline FS 3a-7 & Dye-tracing and maps connecting sinks to springs \\
\hline FS $3 a-8$ & Spring discharge monitoring and hydrographs \\
\hline FS 3a-9 & Potentiometric maps \\
\hline FS 3a-10 & Topographic maps \\
\hline FS 3a-11 & Geologic maps \\
\hline FS 3a-12 & MODFLOW \\
\hline FS 3a-13 & Geochemical models (e.g., PHREEQC) \\
\hline FS 3a-14 & Isotope geochemistry \\
\hline \multicolumn{2}{|r|}{ Institutions } \\
\hline FS 3b-1 & US Geological Survey \\
\hline FS $3 b-2$ & Karst organizations, e.g., NSS, KWI \\
\hline FS $3 b-3$ & Karst literature, e.g., Journal of Caves and Karst Studies \\
\hline FS 3b-4 & Mainstream geological literature \\
\hline FS $3 b-5$ & Networks of academic descendants \\
\hline FS 3b-6 & Teaching and research field stations \\
\hline
\end{tabular}

nature of hermeneutics in making sense of the union of our experiences: we need to collect the stories.

\section{CONCLUDING REMARK}

Our account gives a perspective of nearly a hundred years of evolving thoughts leading to the concept of multiply permeable karst aquifers. While we believe that some aspects of the our constructed story will be new to many readers of this journal, we are particularly struck by the immensity of how many other stories could be constructed from other points 
of views, experiences, and reading. With regard to the latter, we note that the written and oral personal histories cited in this manuscript (e.g., Garrels, 1953; LaMoreaux, 1983; Watson \& White, 1985; Meyer, et al., 1988; Doel, 1989; Mackenzie, 1989; Lowenstam, 1991; Berner, 1992; Mackenzie \& Andersson 2013) have certainly influenced our perspective and deepened our sense-making of our own experiences. As for the experience of constructing this narrative and the new understandings it has brought us, the deepest lesson is the value of oral and written histories. Metaphorically, they serve as outcrops for hermeneutic explorations in any "interpretive and historical science" (Frodeman, 1995, p. 960) such as geology.

\section{ACKNOWLEDGMENTS}

This manuscript has been a work in progress since 2004, when HLV asked LJF, as part of a PhD qualifying exam, the following question: "What insight, if any, does Frodeman's analysis of hermeneutics and geology have for your view of the history of karst science?" These ideas were later refined in an invited presentation to the History of Geology Section by LJF at the GSA Annual Meeting in 2005. Interestingly, both Derek Ford and William White were honored at that meeting for their long academic contributions. LJF further refined this commentary in a session on eogenetic karst at the GSA Annual Meeting in 2012. This paper is greatly indebted for decades of conversation and inspiration with our colleagues in the science of karst and hydrogeology and the constructive comments of three anonymous reviewers.

\section{REFERENCES}

Atkinson T.C., 1977 - Diffuse flow and conduit flow in limestone terrain in the Mendip Hills, Somerset (Great Britain). Journal of Hydrology, 35: 93-110. http://dx.doi.org/10.1016/0022-1694(77)90079-8

Atkinson T.C., 1985 - Present and future directions in karst hydrogeology. Annales de la Societe Géologique de Belgique, 108: 293-296 (in Ford \& Williams 2007, p. 506).

Back W., 1961 - Calcium carbonate saturation in ground water, from routine analyses. U.S. Geological Survey Water Supply Paper, 1535-D.

Back W. \& Hanshaw B.B., 1970 - Comparison of the chemical hydrogeology of the carbonate peninsulas of Florida and Yucatan. Journal of Hydrology, 10: 330-368. http://dx.doi.org/10.1016/0022-1694(70)90222-2

Back W. \& Zötl J., 1975 - Application of geochemical principles, isotopic methodology, and artificial tracers to karst hydrology. In: Burger A. \& Dubertret L. (Eds.) - Hydrogeology of karstic terrains. International Union of Geological Sciences B.3, p. 105-121. (ref. in Ford \& Williams, 1989, p. 548).

Back W., Hanshaw B.B., Pyle T.E., Plummer L.N. \& Weidie A.E., 1979. Geochemical significance of groundwater discharge and carbonate solution to the formation of Caleta Xel Ha, Quintana Roo, Mexico. Water Resources Research, 15: 1521-1535.

http://dx.doi.org/10.1029/WR015i006p01521
Back W., Hanshaw B.B. \& van Driel J.N., 1984. Role of groundwater in shaping the Eastern Coastline of the Yucatan Peninsula, Mexico. In: LaFleur R.G. (Ed.) Groundwater as a geomorphic agent. Boston, Allen \& Unwin, p. 280-293.

Back W., Hanshaw B.B., Herman J.S. \& van Driel J.N., 1986 - Differential dissolution of a Pleistocene reef in the ground-water mixing zone of coastal Yucatan, Mexico. Geology, 14: 137-140. http://dx.doi.org/10.1130/0091-7613(1986)14 $\leq 137$ :DDOAPR $>2.0 . \mathrm{CO} ; 2$

Bear J., 1972 - Dynamics of fluids in Porous Media. Dover Publications, New York, 784 p.

Berner R.A., 1992 - Robert Minard Garrels. In: Biographical Memoirs 61, National Academy of Sciences of the United States of America. Washington, D.C., National Academy Press, p. 195-214.

Best J., 2001 - Damned lies and statistics: Untangling numbers from the media, politician, and the activists. Berkeley, University of California Press.

Best J., 2002 - People count: The social construction of statistics. American Statistical Association, New York, 2 p. http://www.statlit.org/pdf/2002bestasa.pdf

Best J., 2008 - Birds - Dead and deadly: Why numeracy needs to address social construction. Numeracy, 1 (1): Article 6. http://dx.doi.org/10.5038/1936-4660.1.1.6

Bögli A., 1964 - Mischungskorrossion; ein beitrag zum verkarstungsproblem. Erdkunde, 18 (2): 83-92. (in White 1988, p. 409)

Bögli A., 1980 - Karst hydrology and physical speleology, Springer-Verlag, Berlin, 283 p.

http://dx.doi.org/10.1007/978-3-642-67669-7

Bonacci O., 1987 - Karst hydrology. Springer-Verlag, Berlin, 184 p.

http://dx.doi.org/10.1007/978-3-642-83165-2

Bretz JH., 1942 - Vadose and phreatic features of limestone caverns. Journal of Geology, 50: 675-811. http://dx.doi.org/10.1086/625074

Bretz JH., 1949 - Carlsbad Caverns and other caves of the Guadalupe block, New Mexico. Journal of Geology, 57: 447-463. http://dx.doi.org/10.1086/625660

Bretz JH., 1960 - Bermuda: A partially drowned latemature Pleistocene karst. Geological Society of America Bulletin, 71: 1729-1754.

http://dx.doi.org/10.1130/0016-7606(1960)71 [1729:BAPDLM]2.0.CO;2

Budd D.A., 1984 - Freshwater diagenesis of Holocene ooid sands, Schooner Cays, Bahamas. Unpublished Ph.D. thesis, University of Texas at Austin, Austin, $491 \mathrm{p}$.

Budd D.A. \& Vacher H.L., 2002 - Facies control on matrix permeability in the upper Floridan aquifer, west-central Florida: Implications to diffuse flow. In: Martin J.B., Wicks C.M., \& Sasowsky I.D. (Eds.) - Hydrogeology and biology of Post-Paleozoic carbonate aquifers. Karst Waters Institute Special Publication, 7: 14-24.

Budd D.A., Hammes U. \& Vacher H.L., 1993 - Calcite cementation in the upper Floridan aquifer: A modern example for confined-aquifer cementation models? Geology, 21: 33-36.

http://dx.doi.org/10.1130/0091-7613(1993)021 $<0033$ :CCITUF $>2.3 . \mathrm{CO} ; 2$

Budd D.A. \& Vacher H.L., 2004 - Matrix permeability of the confined Floridan aquifer, Florida, USA: Hydrogeology Journal, 12: 531-549.

http://dx.doi.org/10.1007/s10040-004-0341-5

Bush P.W., 1982 - Predevelopment flow in the Tertiary limestone aquifer, southeastern United States: A regional analysis from digital modeling. U.S. Geological Survey Water-Resources Investigations 82-905, 41 p. 
Bush P.W. \& Johnston R.H., 1988 - Ground-water hydraulics, regional flow, and ground-water development of the Floridan aquifer system in Florida and in parts of Georgia, South Carolina, and Alabama. U.S. Geological Survey Professional Paper, 1403-C, 80 p., 17 plates.

Chamberlin T.C., 1885 - Requisite and qualifying conditions of Artesian Wells. U.S. Geological Survey $5^{\text {th }}$ Annual Report, p. 125-173.

Choquette P.W. \& Pray L.C., 1970 - Geologic nomenclature and classification of porosity in sedimentary carbonates. American Association of Petroleum Geologists Bulletin, 54: 207-250.

Darton N.H., 1897 - Preliminary report on artesian waters of a portion of the Dakotas. U.S. Geological Survey $17^{\text {th }}$ Annual Report, part 2, p. 609-694.

Davis W.M. 1899 - The geographic cycle. The Geographical Journal, 14 (5): 481-504.

http://dx.doi.org/10.2307/1774538

Deming D., 2001 - Introduction to hydrogeology. McGraw Hill, 480 p.

Dodd J.R. \& Stanton R.J. Jr., 1990 - Paleoecology: Concepts and applications, $2^{\text {nd }}$ ed. Wiley, $502 \mathrm{p}$.

Doel R.E., 1989 - Interview with Dr. M. King Hubbert. Niels Bohr Library \& Archives with the Center for History of Physics.

Dominico P.A. \& Schwartz F.W. 1990 - Physical and chemical hydrogeology. New York, John Wiley and Sons, 506 p.

Epstein S. \& Lowenstam H.A., 1953 - Temperature-shellgrowth relations of recent and interglacial Pleistocene shoal-water biota in Bermuda. Journal of Geology, 61 (5): 424-438. http://dx.doi.org/10.1086/626110

Fetter C.W., 1988 - Applied hydrogeology, $2^{\text {nd }}$ ed. Upper Saddle River New Jersey, Prentice Hall, 2004, 592 p.

Florea L.J., 2006 - Architecture of air-filled caves within the karst of the Brooksville Ridge, West-Central Florida. Journal of Cave and Karst Studies, 68 (2): 64-75.

Florea L.J. \& Vacher H.L., 2006 - Springflow hydrographs: Eogenetic us. telogenetic karst. Ground Water, 44 (3): 352-361.

Florea L.J. \& Vacher H.L., 2007 - Eogentic karst hydrology: Insights from the 2004 Hurricanes, Peninsular Florida. Ground Water, 45 (4): 439-446.

Florea L.J., Vacher H.L., Donahue B. \& Naar D., 2007 - Quaternary cave levels in peninsular Florida. Quaternary Science Reviews, 26 (9/10): 1344-1361. http://dx.doi.org/10.1016/j.quascirev.2007.02.011

Florea L.F. \& Vacher H.L., 2011 - Communication and "forestructures" at the geological intersection of caves and subsurface water flow: Hermeneutics and parochialism. Earth Science History, 30 (1): 85-105.

Ford D.C. \& Ewers R.O., 1978 - The development of limestone cave systems in the dimensions of length and breadth. Canadian Journal of Earth Science, 15: 1783-1798. http://dx.doi.org/10.1139/e78-186

Ford D. \& Williams P., 1989 - Karst geomorphology and hydrology. Unwin Hyman, London, $601 \mathrm{p}$.

Ford D. \& Williams P., 2007 - Karst hydrogeology and geomorphology. Wiley, West Sussex, 562 p. http://dx.doi.org/10.1002/9781118684986

Ford T.D. \& Cullingford C.H.D., 1976 - The science of speleology. Academic Press, London, 593 p.

Freeze R.A. \& Cherry J.A., 1979 - Groundwater. Englewood Cliffs, Prentice-Hall, New Jersey, 604 p.

Freeze R.A. \& Back W. (Eds.), 1983 - Physical hydrogeology. Stroudsburg Pennsylvania, Hutchinson Ross Publishing Co., Benchmark Papers in Geology, 448 p. (on p. 291).
Freid E.H., 2011 - Review of: Life quest: Building the Gerace Research Centre, San Salvador, Bahamas, Donald T. Gerace. The International Journal of Bahamian Studies, 17 (2): 73.

Frodeman R. 1995 - Geological reasoning: Geology as an interpretive and historical science. Geological Society of America, Bulletin, 107: 960-968.

http:/ /dx.doi.org/10.1130/0016-7606(1995)107 $<0960$ :GRGAAI $>2.3 . \mathrm{CO} ; 2$

Frodeman R. 2014 - Hermeneutics in the field: The philosophy of geology. In: Ginev D. (Ed.) - The multidimensionality of hermeneutic phenomenology. Springer, Berlin, p. 69-79.

Garrels R.M., 1953 - Memorial to Allyn Coats Swnnerton (1897-1952). Geological Society of America Proceedings 1952, p. 143-146.

Garrels R.M. \& Mackenzie, F.T., 1967 - Origin of the chemical composition of some lakes. In: Stumm, W. (Ed.) - Equilibrium concepts in natural water systems. Washington, DC, American Chemical Society p. 222-242.

Ginsburg R.N. \& Lowenstam H.A., 1958 - The influence of marine bottom communities on the depositional environment of sediments. Journal Geology, 66 (3): 310-318.

Green R.T., Painter S.L., Sun A. \& Worthington, S.R., 2006 - Groundwater contamination in karst terranes. Water, Air, \& Soil Pollution: Focus, 6 (1): 157-170.

Gross M.G., 1964 - Variation in the $\mathrm{O}^{18} / \mathrm{O}^{16}$ and $\mathrm{C}^{13} / \mathrm{C}^{12}$ ratios of diagenetically altered limestones in the Bermuda Islands. Journal of Geology, 72: 170-194. http://dx.doi.org/10.1086/626975

Gulley J., Martin J.B., Screaton E.J. \& Moore P.J., 2011 - River reversals into karst springs: A model for cave enlargement in eogenetic karst aquifers. Geological Society of America Bulletin, 123 (3/4): 457-467.

Gulley J., Martin J.B., Moore P.J. \& Murphy, J. 2013 - Formation of phreatic caves in an eogenetic karst aquifer by $\mathrm{CO}_{2}$ enrichment at lower water tables and subsequent flooding by sea level rise. Earth Surface Processes and Landforms, 38: 1210-1224.

http:/ /dx.doi.org/10.1002/esp.3358

Gulley J.G., Martin J.A. \& Moore P.J., 2014a - Vadose $\mathrm{CO}_{2}$ gas drives dissolution at water tables in eogentic karst aquifers more than mixing dissolution. Earth Surface Processes and Landforms, 39 (13): 457-467.

Gulley J.D., Martin J.B., Spellman P., Moore P.J. \& Screaton E.J., 2014b - Influence of partial confinement and Holocene river formation on groundwater flow and dissolution in the Florida carbonate platform. Hydrological Processes, 28 (3): 705-717.

Hallihan T., Sharp J.M., Jr. \& Mace R.E., 1999 Interpreting flow using permeability at multiple scales. In: Palmer A.N., Palmer M.V. \& Sasowsky I.D. (Eds.) - Karst modeling. Charles Town, West Virginia, Karst Waters Institute Special Publication 5: p.

Harmon R.S. \& Wicks, C.M., 2006 - Perspectives on karst geomorphology, hydrology, and geochemistry - A tribute volume to Derek C. Ford \& William B. White. Geological Society of America Special Papers, 404, 366 p.

Heidegger M., 1927 - Being and time. Macquarrie J., \& Robinson E. (Translation). Harper and Row, New York, 589 p.

Helgeson H.C., 1968 - Evaluation of irreversible reactions in geochemical processes involving minerals and aqueous solutions: 1. Theoretical relations. Geochimica et Cosmochimica Acta, 31: 853-877.

http://dx.doi.org/10.1016/0016-7037(68)90100-2 
Helgeson H.C., Garrels R.M. \& Mackenzie F.T., 1969 Evaluation of irreversible reactions in geochemical processes involving minerals and aqueous solutions: 2. Applications. Geochimica et Cosmochimica Acta, 33: 455-481. http://dx.doi.org/10.1016/0016-7037(69)90127-6

Hill C.A., 1987 - Geology of Carlsbad Cavern and other caves in the Guadalupe Mountains, New Mexico and Texas. New Mexico Bureau of Mines and Mineral Resources Bulletin 117, 150 p.

Hill C.A., 1990 - Sulfuric acid speleogenesis of Carlsbad Cavern and its relationship to hydrocarbons, Delaware Basin, New Mexico and Texas. American Association of Petroleum Geologists Bulletin, 74: 1685-1694.

Holland H.D., Kirsipu T.V. Huebner J.S. \& Oxburgh U.M., 1964 - On some aspects of the chemical evolution of cave waters. Journal of Geology, 72: 36-67. http://dx.doi.org/10.1086/626964

Hubbert M.K., 1940 - The theory of ground-water motion. Journal of Geology, 48 (8): 785-944.

Hubbert M.K., 1953 - Entrapment of petroleum under hydrodynamic conditions. Bulletin American Association of Petroleum Geologists, 37: 1944-2026.

Hubbert M.K., 1956 - Darcy's Law and the field equations of flow of underground fluids. Transactions of American Institute of Mining and Metallurgical Engineers, 207: 222-239.

Hubbert M.K., 1969 - Introduction in M.K. Hubbert, The theory of ground-water motion and related papers. Hafner Publishing Company, New York, 300 p.

Jacob C.E., 1940 - On the flow of water in an elastic artesian aquifer. Transactions, American Geophysical Union, 20: 666-674. http://dx.doi.org/10.1029/TR020i004p00666

Jennings J.N., 1971 - Karst. MIT Press, Cambridge, Massachusetts, $252 \mathrm{p}$.

Jones I.C., Vacher H.L. \& Budd D.A., 1993 - Transport of calcium, magnesium and SO4 in the Floridan aquifer, west-central Florida: Implications to cementation rates. Journal of Hydrology, 143: 455-480.

http://dx.doi.org/10.1016/0022-1694(93)90204-M

Jones W.K., 1973 - Hydrology of limestone karst. West Virginia Geological and Economic Survey Bulletin, 36, $49 \mathrm{p}$.

Jones W.K., 1984 - Analysis and interpretation of data from tracer tests in karst areas. National Speleological Society Bulletin, 46: 41-47.

King F.H., 1913 - Movement of ground water. Nineteenth Annual Report United States Geological Survey, 39, Part II.

Kirschvink J.L., 2003 - Heinz A. Lowenstam, 1912-1993. Adapted from the Biographical Memoirs, 83. The National Academy Press, Washington D.C.

Klimchouk A., 2007 - Hypogene speleogenesis: Hydrogeological and morphogenetic perspective. National Cave and Karst Research Institute Special Paper 1, $106 \mathrm{p}$.

KWI (Karst Waters Institute), 1992 - KWI Newsletter, 1 (1).

Lafon G.M. \& Vacher H.L., 1975 - Diagenetic reactions as stochastic processes. Geological Society of America Memoir, 112: 187-204.

LaMoreaux P.E., 1983 - Biographical sketch of Victor Timothy Stringfield. Journal of Hydrology, 61 (1): viii-xii. http://dx.doi.org/10.1016/0022-1694(83)90230-5

Land L.S., 1967 - Diagenesis of skeletal carbonates. Journal of Sedimentary Petrology, 37: 914-930.

Land L.S., 1970 - Phreatic vs. vadose meteoric diagenesis of limestones: Evidence from a fossil water table. Sedimentology, 14: 175-185.

http://dx.doi.org/10.1111/j.1365-3091.1970.tb00191.x
Land L.S., Mackenzie F.T., \& Gould S.J., 1967 Pleistocene history of Bermuda. Geological Society of America Bulletin, 54: 51-74.

http://dx.doi.org/10.1130/0016-7606(1967)78 [993:PHOB]2.0.CO;2

Lane E., 1986 - Karst in Florida. Florida Geological Survey Special Publication 29, 100 p.

Langmuir D., 1971 - The geochemistry of some carbonate ground waters in Central Pennsylvania. Geochimica et Cosmochimica Acta, 35: 1023-1045.

http:/ / dx.doi.org/10.1016/0016-7037(71)90019-6

LeGrand H.E. \& Stringfield V.T., 1971 - Development and distribution of permeability in carbonate aquifers. Water Resources Research, 7: 1284-1294. http://dx.doi.org/10.1029/WR007i005p01284

LeGrand, H.E. \& Stringfield, V.T., 1973 - Karst hydrology - a review. Journal of Hydrology, 20: 97-120. http://dx.doi.org/10.1016/0022-1694(73)90034-6

Lowenstam H.A., 1991 - Interview with Heinz A. Lowenstam [Oral History] (Unpublished). http://oralhistories.library.caltech.edu/66/ [accessed: May 24, 2014].

Mackenzie, F.T., 1989 - Memorial of Robert Minard Garrels, August 24, 1916 - March 8, 1988. American Mineralogist, 74: 487-499.

Mackenzie F.T., \& Andersson A.J., 2013 - The marine carbon system and ocean acidification during Phanerozoic time. Geochemical Perspectives, 2: 1-227. http://dx.doi.org/10.7185/geochempersp.2.1

Martin J.B. \& Dean R.W., 2001 - Exchange of water between conduits and matrix in the Floridan aquifer: Chemical Geology, 179: 145-165. http:/ /dx.doi.org/10.1016/S0009-2541(01)00320-5

Martin J.B. \& Portell R.W., 2002 - A brief introduction to the geology, hydrogeology and natural history of north central Florida. In: Martin J.B., Wicks C.M. \& Sasowsky I.D. (Eds.) - Hydrogeology and biology of post-Paleozoic carbonate aquifers. Karst Waters Institute Special Publication, 7: 205-211.

Martin J.M., Wicks C.M. \& Mylroie, J.E., 2002 Introduction. In: Martin J.B., Wicks C.M. \& Sasowsky I.D. (Eds.) - Hydrogeology and biology of post-Paleozoic carbonate aquifers. Karst Waters Institute Special Publication, 7: 1-2.

Martin J.M., Screaton E.J. \& Martin J.B., 2006 Monitoring well responses to karst conduit head fluctuations: Implications for fluid exchange and matrix transmissivity in the Floridan aquifer. In: Wicks C.M. \& Harmon R.S. (Eds.) - Perspectives on karst geomorphology, hydrology, and geochemistry: A tribute volume to Derek C. Ford \& William B. White. Geological Society of America Special Paper, 404: 209-217.

http://dx.doi.org/10.1130/2006.2404(17)

Maxey G.B., 1979 - The Meinzer era of U.S. hydrogeology, 1910-1940. Journal of Hydrology, 43: 1-6. http://dx.doi.org/10.1016/0022-1694(79)90162-8

McDonald M.G., \& Harbaugh, A., 2003 - The history of MODFLOW. Ground Water, 41 (1): 280-283

Meyer G., Davis G. \& LaMoreaux P.E., 1988 - Historical Perspective. In: Back W., Rosenshein J.J. \& Seaber P.R. (Eds.) - Hydrogeology. Geological Society of America, Boulder CO, The Geology of North America, 0-2: 1-8.

Miall A.D. \& Miall C.E., 2004 - Empiricism and modelbuilding in stratigraphy: Around the hermeneutic circle in the pursuit of stratigraphic correlation. Stratigraphy, 1: $27-46$.

Moore C.H., 2001 - Carbonate reservoirs: Porosity evolution and diagenesis in a sequence stratigraphic framework. Elsevier, Amsterdam, 444 p. 
Moore G.W. \& Sullivan G.N., 1964 - Speleology, the study of caves, D.C. Heath and Company, 120 p.

Moore P.J., Martin J.B. \& Screaton E.J., 2009 Geochemical and statistical evidence of recharge, mixing, and controls on spring discharge in an eogenetic karst aquifer. Journal of Hydrology, 376 (3/4): 443-455.

Moore P.J., Martin J.B., Screaton E.J. \& Neuhoff P., 2010 - Conduit enlargement in an eogenetic karst aquifer. Journal of Hydrology, 393: 143-155.

http://dx.doi.org/10.1016/j.jhydrol.2010.08.008

Morse J.W. \& Mackenzie F.T., 1990 - Geochemistry of sedimentary carbonates. Elsevier Scientific Publishing Company, New York, 696 p.

Muskat M., 1937 - The flow of homogeneous fluids through porous media. New York, McGraw Hill, 763 p.

Mylroie J.E., 1977 - Speleogenesis and karst geomorphology of the Helderberg Plaeau, Schaharie County, New York. New York Cave Survey, Bulletin, 2-3, 36 p. (citation, Palmer, 2006).

Mylroie J.E., 1982 - Karst geology and Pleistocene history of San Salvador Island, Bahamas. Proceedings of the $1^{\text {st }}$ Symposium of the Geology of The Bahamas, p. 6-11.

Mylroie J.E., 1984 - Speleogenetic contrast between the Bermuda and Bahama Islands. In: Teeter J.W. (Ed.) Proceedings of the $2^{\text {nd }}$ Symposium on the Geology of The Bahamas, p. 113-128.

Mylroie J.E. \& Carew J.L., 1990 - The flank margin margin model for dissolution cave development in carbonate platforms. Earth Surface Processes and Landforms, 15: 423-424.

http://dx.doi.org/10.1002/esp.3290150505

Mylroie J.E. \& Carew J.L., 1995 - Karst development on carbonate islands. In: Budd D.A., Harris P.M. \& Saller A. (Eds.) - Unconformities and porosity in carbonate strata. American Association of Petroleum Geologists Memoir, 63: 55-76.

Mylroie J.E., Carew J.L. \& Vacher H.L., 1995 - Karst development in the Bahamas and Bermuda. In: Curran H.A. \& White B. (Eds.) - Terrestrial and shallow marine geology of the Bahamas and Bermuda. Geological Society of America Special Paper, 300: 251-267. http://dx.doi.org/10.1130/0-8137-2300-0.251

Niemann J.C. \& Read J.F., 1988 - Regional cementation from unconformity-recharged aquifer and burial fluids, Mississippian Newman Limestone, Kentucky. Journal of Sedimentary Petrology, 58: 688-705.

Palmer A.N., 1991 - Origin and morphology of limestone caves. Geological Society of America Bulletin, 103: 1-21. http://dx.doi.org/10.1130/0016-7606(1991)103 $<0001$ :OAMOLC $>2.3 . \mathrm{CO} ; 2$

Palmer A.N., 1999 - Introduction. In: Palmer A.N., Palmer M.V., \& Sasowsky I.D. (Eds.) - Karst modeling. Charles Town, West Virginia, Karst Waters Institute Special Publication, 5: 1-9.

Palmer A.N., 2002 - Karst in Paleozoic rocks: How does it differ from Florida? In: Martin J.B., Wicks C.M., \& Sasowsky, I.D. (Eds.) - Hydrogeology and biology of post-Paleozoic carbonate aquifers. Charlestown, West Virginia, Karst Water Institute Special Publication, 7: 185-191.

Palmer A.N., 2007 - Cave geology. Cave Books, Dayton, 454 p.

Palmer A.N. \& Palmer M.V., 2008 - Field guide to the paleokarst of the Black Hills. In: Sasowsky I.D., Feazel C.T., Mylroie J.E., Palmer A.N. \& Palmer M.V. (Eds.) Karst from recent to reservoirs. Karst Waters Institute Special Publication, 14: 157-162.

Palmer A.N., Palmer M.V. \& Queen J.M., 1977 - Geology and origin of the caves of Bermuda. Proceedings of the $7^{\text {th }}$ International Congress of Speleology, Sheffield, U.K., p. 336-339.
Parkhurst D., Charlton S., Riggs A., \& Webb R., n.d. - Reaction-transport modeling in groundwater and watershed systems.

http://wwwbrr.cr.usgs.gov/projects/GWC coupled/

Plummer L.N., 1975 - Mixing of seawater with calcium carbonate ground water: Quantitative studies in the geological sciences. Geological Society America Memoir, 142: 219-236.

Plummer L.N., 1977 - Defining reactions and mass transfer in a portion of the Floridan aquifer. Water Resources Research, 13: 801-812.

http://dx.doi.org/10.1029/WR013i005p00801

Plummer L.N. \& Back W., 1980 - The mass balance approach: Application to interpreting the chemical evolution of hydrogeology systems. American Journal of Science, 280: 130-142.

http://dx.doi.org/10.2475/ajs.280.2.130

Plummer L.N. \& Sprinkle C.L., 2000 - Radiocarbon dating of dissolved inorganic carbon in groundwater from confined parts of the Upper Floridan aquifer, Florida, USA. Hydrogeology Journal, 9: 127-150.

http://dx.doi.org/10.1007/s 100400000121

Plummer L.N, Vacher H.L., Mackenzie F.T., Bricker O.P. \& Land L.S., 1976 - Hydrogeochemistry of Bermuda: A case history of ground-water diagenesis of biocalcarenites. Geological Society of America Bulletin, 87: 1301-1316.

http://dx.doi.org/10.1130/0016-7606(1976)87 $<1301$ :HOBACH $>2.0 . \mathrm{CO} ; 2$

Plummer L.N., Parkhurst D.L. \& Thorstenson D.C., 1983 - Development of reaction models for groundwater systems. Geochimica et Cosmochimica Acta, 47: 665-686.

http://dx.doi.org/10.1016/0016-7037(83)90102-3

Quinlan J.F. \& Ewers R.O., 1989 - Subsurface drainage in the Mammoth Cave area. In: White W.B. \& White E.L. (Eds.) - Karst hydrology: Concepts form the Mammoth Cave area. New York, Van Nostrand Reinhold, p. 65-103. http://dx.doi.org/10.1007/978-1-4615-7317-3_3

Quinlan J.F., 1990 - Special problems of ground-water monitoring in karst terranes. In: Nielson D.M. \& Johnson A.I. (Eds.) - Ground water and vadose zone monitoring. American Society of Testing and Materials, Philadelphia, p. 275-304.

http://dx.doi.org/10.1520/STP23420S

Rhoades R. \& Sinacori M.N., 1941 - Pattern of groundwater flow and solution. The Journal of Geology, 49: 785-794. http://dx.doi.org/10.1086/625014

Ricoeur, P., 1985. Time and narrative, translated by Kathleen McLaughlin and David Pellauer. University of Chicago Press, Chicago, Illinois, 207 p.

Ritorto M., Screaton E.J., Martin J.B. \& Moore P.J., 2009 - Magnitudes and chemical effects of diffuse and focused recharge in an eogenetic karst aquifer: An example from the unconfined Floridan aquifer. Hydrogeology Journal, 17: 1687-1698.

http://dx.doi.org/10.1007/s10040-009-0460-0

Rovey C.W., II, 1994 - Assessing flow systems in carbonate aquifers using scale effects in hydraulic conductivity. Environmental Geology, 24: 244-253. http://dx.doi.org/10.1007/BF00767085

Rovey C.W., II \& Cherkauer D.S., 1995 - Scale dependency of hydraulic conductivity measurements. Ground Water, 33: 769-780.

http://dx.doi.org/10.1111/j.1745-6584.1995.tb00023.x Ryder P.D., 1985 - Hydrology of the Floridan aquifer system in West-Central Florida. U.S. Geological Survey Professional Paper, 1403-F, 61 p. 
Sauter M., Covinton M., Florea L., Gabrovsek F., Gao Y., Green R., Gulley J., Harmon R., Herman E., Jeannin P-Y., Jones W.K., Kincaid T., Moore P.J., Mylroie J., Sasowsky I.D., Screaton E. \& Wicks C.M., 2008 - Focus group on karst hydrology - Conceptual models, aquifer characterization, and numerical modeling. In: Martin J.B. \& White W.B. (Eds.) - Frontiers of karst research. Karst Waters Institute Special Publication, 13: 77-81

Sayles R.W., 1931 - Bermuda during the Ice Age. Proceedings of American Academy of Arts and Science, 66: 381-467. http://dx.doi.org/10.2307/20026356

Screaton E., Martin J.B., Ginn B. \& Smith L., 2004 Conduit properties and karstification in the Santa Fe River sink-rise system of the Floridan aquifer. Ground Water, 42: 338-346.

http://dx.doi.org/10.1111/j.1745-6584.2004.tb02682.x

Shuster E.T. \& White W.B., 1971 - Seasonal fluctuations in the chemistry of limestone springs: A possible means for characterizing carbonate aquifers. Journal of Hydrology, 14: 93-128.

http://dx.doi.org/10.1016/0022-1694(71)90001-1

Shuster E.T. \& White W.B., 1972 - Source areas and climatic effects in carbonate groundwater determined by saturation indices and carbon dioxide pressures. Water Resources Research, 9: 1067-1073. http://dx.doi.org/10.1029/WR008i004p01067

Smart C.C., 1983 - The hydrology of the Castleguard Karst, Columbia Icefields, Alberta, Canada. Arctic and Alpine Research, 15 (4): 471-486. (ref. from Ford and Williams, 2007, p. 204).

Smart P.L. \& Laidlaw I.M.S., 1977 - An evaluation of some fluorescent dyes for water tracing. Water Resources Research, 13: 15-23. http://dx.doi.org/10.1029/WR013i001p00015

Smart P.L. \& Hobbs, S.L., 1986 - Characterization of carbonate aquifers: A conceptual base. Environmental problems in karst terranes and their solutions Conference, Bowling Green, Kentucky, p. 1-14.

Smart P.L. \& Christopher N.S.J., 1989 - Ogof Ffynon Ddu. In: Ford T.D. (Ed.) - Limestones and Caves of South Wales. Cambridge University Press, p. 177-189.

Smart P.L., Beddows P.A., Coke J., Doerr S., Smith S. \& Whitaker F.F., 2006 - Cave development on the Caribbean coast of the Yucatan Peninsula, Quintana Roo, Mexico. In: Harmon R.S. \& Wicks C.M. (Eds.) Perspectives on karst geomorphology, hydrology, and geochemistry - A tribute volume to Derek C. Ford and William B. White. Geological Society of America Special Paper, 404: 105-128.

http://dx.doi.org/10.1130/2006.2404(10)

Smith L.A., Martin J.B. \& Screaton E.J., 2002 - Surface water control of gradients in the Floridan aquifer: Observations from the Santa Fe River sink-Rise system. In: Martin J.B., Wicks C.M. \& Sasowsky I.D. (Eds.) Hydrogeology and biology of post-Paleozoic carbonate aquifers. Karst Waters Institute Special Publication, 7: 44-48.

Speidel D.H., 1996 - A hermeneutic reading of the seismic record: Improbable probabilities. Engineering Geology, 43 (1): 1-3.

Stringfield V.T., 1935 - The piezometric surface of artesian water in the Florida Peninsula. American Geophysical Union Transactions, 16: 524-529.

http://dx.doi.org/10.1029/TR016i002p00524

Stringfield V.T., 1936 - Artesian water in the Florida Peninsula. U.S. Geological Survey Water-Supply Paper, 773-C: 115-195.

Stringfield V.T., 1966 - Artesian water in Tertiary limestone in the southeastern states. U.S. Geological Survey Professional Paper, 517: 1-226.
Stringfield V.T. \& LeGrand H.E., 1966 - Hydrology of limestone terranes in the coastal plain of the southeastern United States. Geological Society of America Special Paper, 33: 1-41.

http://dx.doi.org/10.1130/SPE93-p1

Stringfield V.T. \& LeGrand H.E., 1969a - Hydrology of carbonate rock terrains $-A$ review. Journal of Hydrology, 8: 349-417.

http://dx.doi.org/10.1016/0022-1694(69)90009-2

Stringfield V.T. \& LeGrand H.E., 1969b - Relation of sea water to fresh water in carbonate rocks in coastal areas, with special references to Florida U.S.A. and Cephalonia (Kephallinia), Greece. Journal of Hydrology, 9: 387-407.

http://dx.doi.org/10.1016/0022-1694(69)90086-9

Stringfield V.T. \& LeGrand H.E., 1971 - Effects of karst features on circulation of water in carbonate rocks in coastal areas. Journal of Hydrology, 14: 139-157. http://dx.doi.org/10.1016/0022-1694(71)90003-5

Sun A.Y., Green R., Swenson S. \& Rodell M., 2012 Toward calibration of regional groundwater models using GRACE data. Journal of Hydrology, 422: 1-9. http://dx.doi.org/10.1016/j.jhydrol.2011.10.025

Sweeting M.M., 1972 - Karst landforms. Macmillan, London, $362 \mathrm{p}$.

Swinnerton A.C., 1929a - Changes in base-level indicated by caves in Kentucky and Bermuda (abstract). Geological Society of America Bulletin, 40 (1): 194.

Swinnerton A.C. 1929b - The caves of Bermuda. Geological Magazine, 66 (2): 79-84. http://dx.doi.org/10.1017/S0016756800099921

Swinnerton A.C., 1932 - Origin of limestone caverns. Geological Society of America Bulletin, 43: 663-694. http://dx.doi.org/10.1130/GSAB-43-663

Teutsch G. \& Sauter M., 1991 - Groundwater modeling in karst terranes: Scale effects, data acquisition and field validation. Proceedings Third Conference Hydrogeology, Ecology, Monitoring, and Management of Ground Water in Karst Terranes, Nashville, TN, p. 17-35. (ref. in White, 1999).

Theis C.V., 1935 - The relation between the lowering of the piezometric surface and rate and duration of discharge of a well using groundwater storage. Transactions of the American Geophysical Union, 2: 519-524. http://dx.doi.org/10.1029/TR016i002p00519

Thrailkill J., 1968 - Chemical and hydrologic factors in the excavation of limestone caves. Geological Society of America Bulletin, 79: 19-46.

http://dx.doi.org/10.1130/0016-7606(1968)79 [19:CAHFIT]2.0.CO;2

Tihansky A.B., 1999 - Sinkholes, West-Central Florida. In: Galloway D., Jones D.R. \& Ingebritsen S.E. (Eds.) U.S. Geological Survey Circular, 1182: 121-140.

Torres M.C., 2012 - Origins and characteristics of two paleokarst zones in northwest and central Ohio. Unpublished MS thesis, The Ohio State University, 317 p.

Trescott P.C. \& Larson S.P., 1976 - Supplement to OpenFile Report 75-438. Documentation of finite-difference model for simulation of three-dimensional groundwater flow. U.S. Geological Survey Open-File Report, 76-591, $21 \mathrm{p}$.

Upchurch S.B., 2002 - Hydrogeochemistry of a karst escarpment. In: Martin J.B., Wicks C.M. \& Sasowsky I.D. (Eds.) - Hydrogeology and biology of post-Paleozoic carbonate aquifers. Karst Waters Institute Special Publication, 7: 73-75.

Vacher H.L. \& Mylroie J.E., 2002 - Eogenetic karst from the perspective of an equivalent porous medium. Carbonates and Evaporites, 17: 182-196. http://dx.doi.org/10.1007/BF03176484 
Vacher H.L. \& Rowe M.P., 1997 - Geology and hydrology of Bermuda. In: Vacher H.L., \& Quinn T.M., (Eds.) - Geology and hydrogeology of carbonate islands. Elsevier Science B.V., Amsterdam, p. 35-89.

Vacher H.L., Bengtsson T.O. \& Plummer L.N., 1990 Hydrology of meteoric diagenesis: Residence time of meteoric ground water in island fresh-water lenses with application to aragonite-calcite stabilization rate in Bermuda. Geological Society of America Bulletin, 102: 223-232.

http://dx.doi.org/10.1130/0016-7606(1990)102 $\leq 0223:$ HOMDRT $>2.3$.CO;2

Vacher H.L., Hutchings W.C., \& Budd D.A., 2006 Metaphors and models: The ASR bubble in the Floridan aquifer. Ground Water, 44 (2): 144-154.

Watson R.A. \& White W.B, 1985 - The history of American theories of cave origin. Geological Society of America Centennial Special Volume, 1: 109-123.

White E.L., 1976 - Role of carbonate rocks in modifying flood flow behavior. Water Resources Bulletin, 12: 351-370.

http://dx.doi.org/10.1111/j.1752-1688.1976.tb02684.x

White E.L., 1977 - Sustained flow in small Appalachian watersheds underlain by carbonate rocks. Journal of Hydrology, 32: 71-86.

http://dx.doi.org/10.1016/0022-1694(77)90119-6

White W.B., 1969 - Conceptual models for carbonate aquifers. Ground Water, 7 (3): 15-21.

White W.B., 1988 - Geomorphology and hydrology of karst terrains. Oxford University Press, New York, 464 p.

White W.B., 1993 - Analysis of karst aquifers. In: Alley W.M. (Ed.), Regional ground-water quality. Van Nostrand Reinhold, New York, p. 471-489.
White W.B., 1999 - Conceptual models for karstic aquifers. In: Palmer A.N., Palmer M.V. \& Sasowsky I.D. (Eds.) - Karst modeling, Karst Waters Institute Special Publication, 5: 11-16.

White W.B., 2000 - Development of speleogenetic ideas in the 20 $0^{\text {th }}$ century: the modern period, 1957 to the present. In: Klimchouk A.B., Ford D.C., Palmer A.N. \& Dreybrodt W. (Eds.) - Speleogenesis; Evolution of karst aquifers. National Speleological Society Press, Huntsville, AL, p. 39-43.

White W.B., 2002 - Ground water flow in karst: Matrix flow and conduit flow with implications for the Floridan aquifer. In: Martin J.B., Wicks C.M. \& Sasowsky I.D. (Eds.) - Hydrogeology and biology of post-Paleozoic carbonate aquifers. Karst Waters Institute Special Paper, 7: 9-13.

White W.B. \& Culver D.C. (Eds.), 2007 - Benchmark papers in karst science. Karst Waters Institute, Leesburg, VA, 590 p.

White W.B. \& White E.L., 1989 - Karst hydrology: Concepts from the Mammoth Cave region. Van Nostrand Reinhold, New York, 346 p. http://dx.doi.org/10.1007/978-1-4615-7317-3

Wilson W.L., 2002 - Conduit morphology and hydrodynamics of the Floridan aquifer: Moving to the next level - conduit modeling. In: Martin J.B., Wicks C.M. \& Sasowsky I.D. (Eds.), Hydrogeology and biology of post-Paleozoic carbonate aquifers. Karst Waters Institute Special Publication, 7: 5-8.

Worthington S.R.H., 1999 - A comprehensive strategy for understanding flow in carbonate aquifers. In: Palmer A.N., Palmer M.V. \& Sasowsky I.D. (Eds.) - Karst modeling. Charles Town, West Virginia, Karst Waters Institute Special Publication, 5: 30-37. 